\title{
Sustainability Impact Assessment (SIA) in fisheries: Implementation in EU fishing regions
}

\author{
Malvarosa Loretta ${ }^{1,}{ }^{*}$, Murillas Arantza ${ }^{2}$, Lehuta Sigrid ${ }^{3}$, Nielsen J. Rasmus ${ }^{5}$, Macher Claire ${ }^{4}$, \\ Goti Leyre ${ }^{6}$, Motova Arina ${ }^{7,8}$, Doering Ralf ${ }^{6}$, Haraldson Gunnar ${ }^{9}$, Accadia Paolo ${ }^{1}$, Hamon Katell ${ }^{10}$, \\ Bastardie Francois ${ }^{5}$, Maravelias Christos D. ${ }^{11}$, Mardle Simon ${ }^{12,13}$, Thøgersen Thomas ${ }^{5}$
}

${ }_{1}^{1}$ NISEA, Fishery and Aquaculture Research Organisation, Salerno, Italy

${ }^{2}$ AZTI, Txatxarramendi Ugartea z/g., E-48395 Sukarrieta, Bizkaia, Spain

3 Ifremer, Fisheries Ecol and Modelling Unit, F-44311 Nantes 03, France

4 Ifremer, University of Brest, CNRS, UMR 6308, AMURE, Unité d'Economie Maritime, IUEM, F-29280

Plouzane, France

${ }^{5}$ DTU Aqua - National Institute of Aquatic Resources Technical, University of Denmark, Lyngby,

Denmark

${ }^{6}$ Thünen-Institute of Sea Fisheries, Bremerhaven, Germany

7 Joint Research Centre, Directorate D - Sustainable Resources, Unit D.02 Water and Marine

Resources, Ispra, Italy

${ }^{8}$ Sea Fish Industry Authority, EH7 4HS Edinburgh, UK

9 loES, The Institute of Economic Studies, University of Iceland, Reykjavik, Iceland

10 Wageningen University and Research, Wageningen Economic Research, The Hague, the

Netherlands

${ }^{11}$ HCMR, Hellenic Centre for Marine Research, Attiki, Anavyssos, Greece

12 Fishor Consulting, Portsmouth, UK

${ }^{13}$ FRO, Department of Food and Resource Economics, Faculty of Science, University of Copenhagen,

Denmark

* Corresponding author : Loretta Malvarosa, email address : malvarosa@nisea.eu

\begin{abstract}
:
An Impact Assessment (IA) is a process aimed at structuring and supporting the development of policies. Besides the fact that IA assumes different features when applied to different sectors, really it should help policy makers in evaluating the contribution to the fisheries sustainability of new regulations. The recent improvements and development around the IA methodologies go more and more toward the concept of a Sustainability Impact Assessment (SIA). The evolution of IA in the fishery sector has followed the general and increasing need in having a more and more integrated type of analysis, focusing on the three dimensions of sustainability (environmental, economic and social). This paper synthesizes the methodology developed under the EU FP7 SOCIOEC project, 1 whose main objective was the application of the most recent EU guidelines on IA to the current (and future) EU fishery management. The result is an integrated approach taking into account the main pillars of sustainability and a strong stakeholders' involvement. A clear step-by-step procedure based on both qualitative and quantitative type of analyses has been defined, the last step being the "rating" phase, an essential step in a SIA, that provides the
\end{abstract}


possibility to assess the results of different policy options (allowing policy makers to select the most appropriate one) in terms of acceptability, effectiveness, coherence and efficiency. The overall methodology has been tested on different EU regions, fisheries and management measures.

Keywords: Impact assessment, Fishery management, Effectiveness, Coherence, Acceptability, Sustainability 


\section{Introduction}

One of the most integrated Impact Assessment (IA) systems is the "impact assessment guidelines" ([1], [2]) proposed by the European Commission based on public consultation. According to these guidelines, IA is "a process aimed at structuring and supporting the development of policies" and can be regarded as "a set of logical steps to be followed in preparing policy proposals". Further, "it identifies the main options for achieving the objective, outlines advantages and disadvantages of each option and examines possible synergies and trade-offs" and "it enlightens decision makers on the advantages and disadvantages of possible policy options by assessing their potential impacts".

However, even if it can be assumed that Member State governments use IA to assess policy, according to [3] "only in a small number of jurisdictions is IA used as a strategic instrument for policy integration and sustainability" and IA is mostly seen as a tool "to reduce administrative burden and the economic cost of regulation".

The recent improvements and development around IA methodologies go more and more towards the concept of a Sustainability Impact Assessment (SIA), which is a methodological policy instrument for developing integrated policies. The increasing need of a more holistic approach to policies' development as well as of a longer-term approach (i.e. policies taking into account effects in the long-run), can be satisfied only with a more sustainable and integrated approach. SIA, indeed, takes full account of the three pillars of sustainable development (i.e. ecological, economic and social) and provides a process for assessing the likely (long term) economic, social and environmental effects of policies, strategies, plans and programs before they have been formulated (ex-ante) [4]. Key elements of a SIA are the combined consideration of "hard" (quantitative) and "soft" (qualitative) forms of analysis and a wide stakeholder involvement. Soft methods increase awareness of the wider implications of policies and counterbalance the methodological limits of monetising impacts deriving from hard methods (see [4]).

The first identified attempt of using SIA for the evaluation of EU fisheries management was carried out under the umbrella of the Scientific, Technical and Economic Committee for Fisheries (STECF) by a study group on the development of protocols for multiannual plan IA [5]. In general, a SIA analysis should answer some key questions [1], e.g. what is the nature and the scale of the problem?, how is it evolving and who is most affected by it?, which objectives should be set to address and solve the problem?, what are the views of the concerned stakeholders?, what are the main policy options for reaching these objectives?, what are the likely economic and social impacts of those options?, how do the main options compare in terms of effectiveness, efficiency and coherence in solving the problems?, and how do the main options compare in terms of acceptability? Furthermore, several methods or tools of analysis can be used depending on the stage of the assessment, the desired depth of the analysis and the specific impacts to be examined [6], e.g. Cost benefit Analysis (CBA), modelling tools, bio-economic models or, in case of data poor situations, more empirical analysis based on proxies. In fact, it is often a combination of tools that are needed for an integrated assessment.

One of the main aims of the EU funded project SOCIOEC ${ }^{1}$ was the improvement of IA methodologies to assess fisheries management options. For that, the project partners analysed social and economic impacts of a wide variety of management measures (implemented and proposed management measures). The improvements and development around the IA methodologies integrated the concept of a Sustainability Impact Assessment (SIA) as described above. This paper represents a synthesis of the SIA methodology developed and applied under that project, with the aim to contribute to the science and methodology of IA by developing a framework to carry out a SIA to achieve policy integration and sustainability in the context of EU fisheries management. The framework and resulting analysis drew on the various issues addressed by the project that affect decision-making processes in fisheries, including the definition of management objectives, incentives and fishermen's behaviour under different management options, governance structures and stakeholder involvement. The analysis covered the major EU fishing regions (NorthEast Atlantic, North Sea, Baltic Sea, Western Waters and Mediterranean Sea), which allowed the consideration of the main features of different fisheries management options implemented EU-wide.

The main aim of this paper, through practical examples and implementations, is to show how SIA can be used to evaluate the applicability of new management measures, considering both the ecological, economic and social dimensions in the evaluation of the impacts as well as the acceptability, efficiency, effectiveness and coherence criteria, required by the most advanced general protocols on IA [1]. The paper provides, in a systematic way, the main steps to follow for a possible and efficient implementation of SIA in fishery management. Furthermore, the applied use of the SIA concept is evaluated through its practical application to selected case studies.

\section{Material and methods}

The SIA has been tested on selected case studies, these are:

- Fehmarn Belt small scale fishery

- Western Baltic large-scale fisheries

- $\quad$ North Sea flatfish fishery

\footnotetext{
${ }^{1}$ SOCIOEC, Socio economic effects of management measures of the future CFP, grant agreement No 289192 (7th Framework Program).
} 
- Italian Northern Adriatic demersal fishery

- Greek Aegean demersal fishery

- Eastern English Channel mixed fishery

- Bay of Biscay sole fishery

- Basque fisheries

- North East Atlantic pelagic fisheries considering international ITQs

- Icelandic inshore hand-line fishery

The case studies are set in different socio-economic contexts covering a wide range of vessel types and fleet compositions. In general, the case studies cover a wide variety of elements, namely a) different EU regions (Baltic Sea, North Sea, Western Waters and Mediterranean) and non EU regions (Iceland); b) different fisheries, from coastal to distant water fisheries, from demersal to pelagic fisheries; and c) different management measures: already implemented (but subject to change), to be implemented but with uncertainty about implementation settings and effects (e.g. landing obligation), and at the proposal stage (e.g. potential application of effort quota in the Mediterranean Sea). Furthermore, the case studies build on; d) different levels of data and/or model availability: from data-poor situations (e.g. Fehmarn Belt small scale fishery) to (almost) fully documented fisheries (e.g. the Western Waters fisheries in the Bay of Biscay); and e) different levels of stakeholder involvement: from full involvement over the three phases of the SIA (e.g. Italian demersal trawlers case study) to lesser involvement (e.g. North Sea flatfish fishery) where stakeholders' views have been integrated from other projects or events.

With regard to management measures, the landing obligation and transferable fishing concessions were considered as two important 'new' measures to impact the EU fleet in forthcoming years. The landing obligation was considered under alternative management scenarios in several case studies, e.g. mixed demersal fisheries [7] and flatfish fisheries in different regions. Transferable fishing concessions or ITQ/ITE were also included as alternative scenarios under some case-studies. Other alternative scenarios are represented by spatial and/or temporal restrictions with a possible re-allocation of fishing effort. Variations in the governance system that promote the participation of stakeholders in the decision-making process are expected to increase the level of compliance with regulations and the efficiency of management measures. Changes in exogenous factors were considered for each of the management options and case studies, including fuel prices, fish prices, and governance (producer organization involvement, tradability of quota, etc.). In terms of biological (i.e. stock abundance) indicators, changes in stock spatial distribution and low recruitment were considered by some case studies as external risk factors.

The SIA approach developed comprises four phases that should be undertaken. The first three phases are ex-ante and should be completed before the implementation of a policy, namely (I) problem identification, (II) option specification and (III) analysis, whereas the fourth phase (IV) is an ex-post evaluation (follow up) of the selected and implemented policy option. In each phase, the steps of the SIA (shown in Figure 1 comprise key questions to be addressed and their responses. Under each step different methodologies and tools can be used to enable response to the questions posed. The selection of the most appropriate analysis tools is influenced by: a) the stage of the assessment (ex-ante / ex-post); b) the depth of the assessment required (e.g. time availability) and; c) the available resources (e.g. data availability). The SIA procedure described in this paper uses qualitative methods and tools such as focus groups ([8] [9]) and quantitative tools such as bio-economic modelling and Cost-Benefit Analysis (CBA) ([10] [1]). The exante phases have been covered by all the case studies evaluated, using data and models available, noting that some differences exist relating to the depth of analysis possible and the type of tools used.

\section{$91 \quad$ Figure 1 here}

\subsection{Qualitative methods: problem identification and option specification}

This section focuses on Phase I (problem identification) and Phase II (option specification) of the SIA procedure illustrated in Figure 1. In particular, Phase II aims to specify the policy options ("option specification") required to solve the main problems identified in Phase I.

In the assessment of impacts of fisheries management measures, the use of qualitative tools is a more recent addition to the analysis toolkit than quantitative tools, developed in many cases due to the lack of quantitative data. However, with the gradual increase in scope and data availability in fisheries data collection in the EU (EC Reg. 1543/2000, 1639/2001, 1581/2004, 199/2008, 665/2008, 93/2010 and more recently Commission decision 2016/1251) as well as expertise in fisheries social sciences [11], qualitative methods by themselves or in connection with quantitative methods increasingly present an important supplement and integrated contribution to the quantitative analyses of economic and social impacts of fisheries management measures.

There are different phases where qualitative analyses may have a key role. When a new management measure or a change in an existing one is proposed, there is a need to evaluate the scale of the problem, how this problem has evolved or is evolving and who are the main subjects affected (Phase I). There is also a need to analyze the objectives of this new proposed measure, in order to clearly define the targets against which the impacts can be measured. As far as the nature and the scale of the problems, key questions such as the potential problems deriving from the implementation of the discard ban or an area closure driving from the implementation of the EU Maritime Spatial Planning (MSP) have been addressed by means of a qualitative approach. For example, high level objectives of these new proposed policy changes have been addressed using interviews and focus groups. This apparently trivial point (as objectives are set in the legislation, [12] art. 3) needs in fact a thorough qualitative analysis, as "unclear objectives" have been claimed to be one of the main concerns of successful management implementation of the former Common Fishery Policy, CFP [13]. In the current study, a workshop was carried out with the aim to discuss high level objectives of the CFP in connection 
with the three sustainability pillars through a strong participation of stakeholders. ${ }^{2}$ To explore how these overarching objectives apply to different management measures, qualitative studies using telephone interviews, focus groups and semi-structured interviews were made. It was observed that the objectives of the fishermen and other stakeholder groups affected by management measures are not always obvious. Some NGOs and fishermen can, for example, find social objectives more relevant than ecological and economic ones ([14], [15]). As a result, qualitative analyses will, indeed, provide important information in framing the impact analysis. Interviews with fishermen can, for instance, be used to verify economic data (e.g. in a focus group one fisherman might contradict another, in interviews trust can be built to obtain data for checking) or, as in the case of Western Baltic Fehmarn fisheries, help to identify new sources of quantitative economic data and evaluate the uncertainty in qualitative analyses. Another area where qualitative analyses contribute significantly to SIA is the analysis of governance aspects (Phase I and II). Governance structures, with varying degrees of co-management and management of access rights, can condition the impact of many measures (see a comparison inside the Western Waters case study in [16]. Knowing the structures and functioning of a governance arrangement is key, because it affects the management measure whose impact is under analysis. Finally, the SIA process has benefited from qualitative techniques such as focus groups by adapting model assumptions. This has been done by including the feedback received by the stakeholders, presenting them with the results of the first round of simulations, such as in the Mediterranean Northern Adriatic case study of implementing effort quota. In that case, the qualitative analysis carried out by involving stakeholders was extremely important as the management measure analyzed is new for that fishery..

\subsection{Quantitative methods: in-depth IA and rating options}

A good SIA should provide evidence to policy makers, in charge of taking the final decisions on the best policy options. Quantification that is clear, concise and able to provide a complete representation of the situation enables a stronger analysis and SIA to be presented. Therefore, the aim of the quantitative phase in a SIA analysis is to provide clear and quantifiable information (e.g. indicators) on the impacts and sustainability of the policy options in order:

1. to compare them against one another;

2. to compare them against the status quo (baseline scenario) and

3. to rate them after their evaluation according the general criteria of effectiveness, efficiency and coherence [1] ${ }^{3}$.

These comparisons represent the core of Phase III (analysis) and, in the light of the step-by-step scheme presented in Table 1, provide a preliminary in depth quantitative analysis (step 4 of the ex-ante phases) aimed at providing results to enable choosing the best options able to achieve the objectives set (rating, step 5).

Once the problem (fishery description and main policy problems) and objectives have been well defined in general terms (e.g. decrease in fishing mortality, increase in the economic viability of the sector, increase in social stability) and a set of alternative management measures have been identified as likely to be applied (stakeholder consultation being essential in this phase), the next step in the quantification of impacts is the definition of the most appropriate indicators able to measure the impact of these management options to assess whether and to what extent the objectives can be achieved. As evidenced by a vast literature ([17]; [18]) and projects ([19], [20] and [21]), the importance attached to environmental/biological and socio-economic indicators have greatly increased over the last decades. Since the early ' 90 s, indicator-based approaches to management have been widely used to provide rapid assessments of the successes and failures of fishery management systems with regard to the major dimension of sustainability [22]. It has been argued that the number of indicators chosen should be minimal to avoid redundancy (e.g. [23]). Furthermore, in order to evaluate if a management option is able to reach predefined objectives, these have to be measured by a set of indicators and these (indicators) have to be evaluated against a set of specific reference points. As reported in [24], reference points can be associated with either critical or optimal states, where the former identifies a limit which must not be exceeded due to possible undesirable consequences (LRPs, limit reference points) and the latter a target to be attained by the system to maximize benefits from the fishery (TRPs, target reference points).

The quantitative analysis has been applied following a standardized structure for each case study. An example of the path followed under the quantitative phase is reported in Table 1, showing the innovative management measures to be evaluated, the general and specific objectives (targets), the selected indicators and reference points and the tool used for the simulation of the Northern Adriatic case study.

\section{Table 1 here}

The in-depth analysis (Step 4 of Phase III according to Figure 1) was conducted using a scenario approach that can be represented by a matrix where rows are the scenario alternatives and columns represent changes in external factors (Error! Reference source not found.). Alternatives are defined by a mix of aspects such as a description of the structure, timing and entity used for the implementation of a management tool. Indeed, a new management tool such as introducing the ITQ system or the landings obligation can be implemented and applied in different ways. For instance, a discard ban deriving from the landings obligation can be applied to different groups of species or to discards exceeding more than a certain percentage of total catches. Each "group of species" or "percentage value" defines a different alternative. External factors are exogenous variables and not easily predictable, like changes in oil prices, fish prices or interest rates. Note that External factor 0 corresponds to the model's basic assumptions.

\footnotetext{
${ }^{2}$ A high-level stakeholder workshop was conducted in Vigo in April 2012 together with the MYFISH project to discuss the overarching sustainability objectives [14].

${ }^{3}[1]$ talks about a ranking phase, where the policy options are ranked according to a hierarchical order, and the order is defined by the evaluation results. The authors of this paper have decided to go for a rating phase being aware that the aim of a SIA is to provide policy makers with the necessary information to evaluate (rating) the different management measures proposed (e.g. if able to achieve the targets; what is the net benefit arising from the implementation of each measures, etc......). It is then up to policy makers to conclude with the selection of the best option (ranking).
} 
For all case studies, where data has allowed, each scenario has been developed using bio-economic models. In case studies with poor data, e.g. the Western Baltic Fehmarn Belt case study, a more basic quantitative analyses was applied. Examples of the models used are described in detail in $[25,26]$.

An essential phase in a SIA analysis, especially if considering the ex-ante typology, is the rating of options (Step 5, Phase III). The aim of any ex-ante SIA is, indeed, to collect all the necessary information to be able to evaluate if a policy option to be implemented is likely to achieve the objectives identified. Following the EU general guidelines [1], the rating process should include three major evaluation criteria: effectiveness, coherence and efficiency. Based on our findings, a fourth criterion regarding acceptability has also been included. These four criteria are described below:

Effectiveness, In a SIA for fishery management, effectiveness is the extent to which the main objectives set by policy makers (possibly in consultation with stakeholders) in terms of environmental, economic and social sustainability are achieved by the proposed management measures. If a quantification is provided, the evaluation of effectiveness provides a measure of the goodness of the policy implementation. Specific effectiveness indicators have been implemented and applied to the case studies investigated. According to the developed approach [27], the results of the simulations (Figure 1, Phase III, step 4) - representing the results of the potential future policy scenarios - have been evaluated against TRP or LRP by specific indicators, namely a Target Effectiveness Indicator (TEI) or a Limit Effectiveness Indicator (LEI), respectively. According to TEI and LEI, effectiveness is measured by if and by how much targets are achieved, including a comparison with the baseline scenario. ${ }^{4}$ TEI and LEI indicators can be synthesised by using a graphical visualization, e.g. by means of a traffic light system, according to [27].

Coherence refers to the extent to which management options (i) are coherent with the overarching objectives of the CFP and operational objectives defined for the management options and (ii) are likely to limit trade-offs between environmental, social, economic and governance dimensions of the fishery [1]. In order to make any conclusions on trade-offs, knowledge about the degree of achievement of objectives should be obtained for all the considered dimensions and then potential conflicts should be evaluated [28]. In the light of this, the coherence evaluation is based on the previous effectiveness evaluation, as well as on qualitative knowledge and varies from case to case depending on the fishery context. Substantially, the coherence evaluation is based on how much the TEI and LEI create trade-offs among the different dimensions in terms of effectiveness. In other words, it is an evaluation about a balanced or unbalanced achievement of objectives across the different dimensions.

Efficiency consists in evaluating, for each alternative management measures, the extent to which objectives can be achieved for a given level of resources or at least cost (i.e. the best relationship between resources employed and results achieved). An option is considered to be justified when it promises the greatest net benefits (i.e. total benefits minus total costs). The Cost-Benefit Analysis (CBA) methodological approach ([10]; [1]) has been applied by estimating, for each scenario, either the streams of future costs and benefits, summed, and placed into their "current" year value or the Net Present Value. Note that NPV gives the stream of benefits minus the stream of costs, discounted to reflect the future point in time in which the various benefits or costs are to occur [29]. Efficiency has been projected in the short-run (to 2018) and the long-run (to 2026).

Acceptability is the extent to which key stakeholders are likely to accept the management measures and the extent to which fishermen have incentives to comply with them. The acceptability evaluation is essential, especially ahead of the implementation of a new management option, as it could improve/worsen compliance and therefore reduce/increase the enforcement costs. The level of compliance/acceptability of a management option might be influenced by different aspects, related to the management/governance system (top-down, self and co-management options affects this measure in the different way as emerged during the project under the governance analysis) and by a series of social factors, e.g. imitation effect, peers' judgement, positive/negative incentive accompanying the management tool, etc. Fishermen are more likely to accept and comply with regulatory management they perceive as easy to apply, effective and fair [30]. The evaluation has been substantially based on a qualitative analysis carried out by means of interviews or by deriving information on experiences of similar existing management options.

It is essential that the results of the evaluation analysis, carried out according to the four criteria and methods illustrated above identify the key elements necessary for policy makers to choose the best policy option and are made available to them in an easily understandable manner. One of the most appropriate ways is a table in which information can be presented to facilitate comparison and decision-making [1] or a decision table [28] like the one developed by the authors, an example of which is reported in Table 3.

\section{Table 3 here}

\section{Results: problems and options' specification}

The main features of the SIA analysis carried out on the investigated EU fisheries, including management measures and scenarios, according to the ex-ante phases of the analysis (SIA) are reported in Table 4.

\footnotetext{
${ }^{4}$ In case of using a TRP, the effectiveness evaluation should take into account: 1) if the results are leading towards the objective goals (i.e. targets) and 2) if the results show an improvement compared to the current situation (especially for environmental/biological indicators). On the other hand, when an indicator is compared to a LRP, the limit level and the starting point (current situation) should be considered in two different and subsequent steps: 1) compare separately the indicator value with the LRP and the indicator value with the starting point (current value) and 2) make a synthesis of the two previous comparisons [27]
} 
To show the SIA application, this paper considers a number of key issues identified during the Phase I (problem identification) across the different case studies, i.e. impact of gillnet fishing, area closures deriving from the implementation of the EU MSP, the landing obligation (LO), as well as overexploitation and overcapacity. Problems focused upon have been identified in the text by using lists with capital letters (e.g. A, B, etc...). For each case study, an explanation of the options found at case study level is provided - Phase II (option specification) to solve the main problems identified in Phase I. Finally, the results of simulations from the options carried out in Phase III (analysis) by using specific modelling tools are described.

\section{Table 4 here}

Given that most of the considered problems and adopted management solutions have been very recently introduced (or represent only a proposal for new management solutions, e.g. effort quota in Adriatic) this research has exclusively focused on the ex-ante stage (Figure ). It is important to note that there has been a need to reply to requests of evaluation for management measures recently introduced (i.e. LO). In such cases, the approach has been used to consider options already decided by policy makers limiting the possibility in these cases to involve stakeholders (e.g. in Phase II as they may be against LO), both in options' and in objectives' specification. As far as the latest, the first set of objectives was short-listed by a long list of indicators discussed in previous projects [31]. This short list (reported in Table 1) was in most case studies discussed with stakeholders and accepted by them. It is worth emphasising that the analysis phases (II and III) of the SIA application have adopted a multidimensional scale through identifying not only ecological but also, economic and even social related issues.

The main results of the SIA application, by case study, main problems identified and different phases (I,II and III) are synthesised in table 5.

\section{Table 5 here}

\section{Discussions: strengths and weaknesses of the method}

Coherence evaluation and trade-off between objectives. The objectives of fisheries management must encompass the environmental, social, economic and governance dimensions of the fishery [1]. What makes fisheries management so difficult is the existence of conflicting objectives: an important component in the SIA process is actually the evaluation of these conflicts and the existence of potential trade-offs. Ideally, all conflicts need to be identified with suitable and acceptable compromises found before the implementation of a new regulation, so that the reconciled set of operational objectives can be simultaneously achieved. The most common conflict, in fishery management, is between maximising short-term economic returns from a fishery without running the risk of waiting for long-run (better) economic results. Take for instance, the example from the Greek demersal trawler case study for which the simulated effort displacement resulted in increased catches of non-juveniles and benefits for profits, catches and stock status were still evident but in all scenarios a decrease in both catches and profits of the trawler fleet was observed in the first year of implementing the closure of hake nurseries to trawling. This trade-off is most often the consequence of the tragedy of the commons applied to fisheries. If there is no "commons" problem, this conflict reduces to a simple investment/harvest decision for fishermen [28] as in the long term maximising economic returns is in line with maximising stock sustainability. Constraints on other ecological issues may well limit the level of economic returns available. A conflict that can present an issue in the long-term is between the social objective (often described by employment in fisheries) and the objectives of economics and environment. The Bay of Biscay sole fishery case study provides an example of it, given that moving into a new ITQ governance system from the current comanagement to tackle overcapacity and overexploitation highlighted trade-offs between economic efficiency and social objectives. When it is impossible to give priority to any objective without impairing others, [28] proposes that using the best combination of scientific knowledge, stakeholders' involvement and negotiation processes, results in "a set of operational objectives that can realistically be obtained from the fishery". Indeed, specific objectives may change during the SIA process by gaining more insight into the effectiveness and efficiency of various policy options [1]. For example, the Basque fisheries case study shows that social benefits were gained by fishermen under the Producer Organisation. In the light of this, the coherence evaluation, and, in particular the trade-off in the achievement of different objectives in relation to the different dimensions - environmental, economic and social is essential in a SIA, especially in an ex-ante analysis.

The value of feeding the quantitative approach using qualitative inputs. The main strength of the SIA is in the incorporation of "soft" (i.e. qualitative) data, obtained by interviewing and collecting information from different stakeholders into the different steps of the impact analysis process. The inclusion of feedback from the real world during the simulation process enables better defined models, as often theoretically well refined models can miss reference to real-world situations typically as a result of important underlying assumptions lacking realism of the main characteristics of the fisheries management problems. These multi-dimensional characteristics can be social, cultural, economic, environmental or political. All case studies evaluated benefit from including this "soft" approach, for instance defining qualitative targets using stakeholders' recommendations (i.e. Eastern English Channel mixed fishery), debating about the current management system's strengths and limitations and, even proposing the implementation of an effort quota system after discussion with stakeholders (i.e. Italian Northern Adriatic demersal fishery). All these case studies show that the combination of quantitative and qualitative approaches is helpful when: (i) defining management objectives and policy instruments, possible scenarios, and constraints; (ii) settings the quantitative methods and models, (representation of the stocks, fishery, modelled processes and behaviours, relevant output indicators, etc.) and particularly fishers' decision-making process and (iii) providing feedback in an integrated qualitative process on scenario results as well as on parameter settings and functional relationships used in the models. 
i. $\quad$ Setting the scene. By making the modeller aware of a variety of stakeholder views, the qualitative approach should support that these different views are incorporated in the modelling process. Some stakeholders may emphasize social issues, such as equity, jobs and traditional fishing methods, while others may emphasize environmental sustainability, risk reduction, and biological diversity. A third group may put greatest weight on economic or even political goals. To incorporate all the different goals and perceptions of reality into the analyses is complicated. It may be possible to have a predetermined set of the aims of fisheries management and using some weighing procedure to represent different viewpoints of stakeholders and associated scenario outcomes.

ii. $\quad$ Fishermen decision-making. Neglecting the varying response to regulations, fish availability and market dynamics has been evidenced as a major reason for management failures [72]. In quantitative approaches, dynamics can be modelled relating to, among others, economic behaviour (short term and long-term investments), fishing choices (vessel type, gear, effort allocation, etc.), compliance behaviour in relation to regulations, etc.., most of the time without being able to figure out the causes for such behaviours. The qualitative models have their advantages as they allow for 1) in depth knowledge of the reasons and background for specific behaviours and variability between actors, 2) insight into stakeholder perceptions of the system/dynamics (parameter settings and functional relationships) and/or 3) stakeholders' attitudes towards regulations. Some of the main drivers and constraints identified in the different case-studies object of analysis are based on the type of governance system adopted, i.e. from top-down to co-management systems (institutional), price of inputs and outputs (economic), stock status perceived by stakeholders (social) and the stock status (environmental). These multidimensional drivers influence the fishermen behaviour and may produce large unintended consequences on the performance of the management and the empirical or operational incentives. The research has been especially devoted at introducing a wider participatory system. As already mentioned, qualitative methods by themselves or in connection with quantitative ones, could play an important role in the analysis of economic and social impacts of fisheries management measures. Including a qualitative stage in the SIA and promoting co-management processes could itself represent an institutional driver influencing, as such, along the process, fishermen's behaviours and therefore, conditioning and potentially filling the gap between intended (goal) and actual incentives (Figure 2). An example is provided by the North East Atlantic pelagic fisheries case study which shows how the introduction of an ITQ system across countries might improve total welfare gain (compared to a national ITQ). However, fishermen behaviour and attitudes towards this ITQ system vary across countries given the presence of winners and losers, increasing the gap between the intended and the operational objectives. On the contrary, moving into an IQ system from a top-down management produces right incentives, reducing that gap, as it has tested through the Basque blue-fin tuna fisheries case study.

\section{Figure 1 here}

iii. Scenarios results evaluation and feedback. Linking the "soft" data with the "hard" (i.e. quantitative) data helps to further refine the models and test the model comprehension. The interaction between the quantitative and qualitative impact assessment is essential to interpret and evaluate correctly the outcomes of the models and their scenario results given the input assumptions of operating models [73, 74]. For example, the SIA for the Greek Aegean demersal fishery case study resulted in an adaptation of the model using stakeholders' feedback

The choice of a specific model for each case study, possibly fed by stakeholder inputs, guaranteed the appropriateness of the model to address the specificities of each fishery and the possible evaluation of management measures. The drawback lies in the difficulty in comparing the different model outcomes on the same basis which complicates the communication of assumptions and results to stakeholders and managers and the comparisons across case studies. An exception is provided by the North East Atlantic pelagic fisheries case study which applies a unique model IMPSEL to analyse the implementation of an ITQ across countries. When tradeoffs across pillars exist, conflicting objectives may also occur within a pillar, as occurs, for instance, in the Eastern English Channel fishery where, as far as the biological dimension, the management for sole also benefits plaice that is caught simultaneously but the effects on red mullet vary according to the level of opportunism hypothesized for fishermen. For instance, environmental/biological

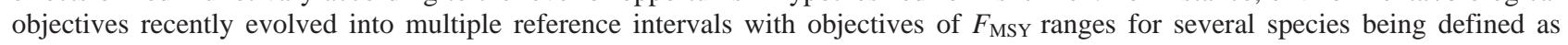
content of the new regional Multiannual Management Plans. This could lead to a change in paradigms for SIA from using a simulation based approach to using a viability approach [75]. Viability theory look at defining viable solutions in the multidimensional viability kernel defined by the ecological and/or biological constraints (multi-species $F_{\text {MSY }}$ ranges constraints and $\mathrm{Bpa}^{5}$ constraints) and the socio-economic constraints (on profit, employment, etc...) [76]. This provides a basis to find the most acceptable and coherent solutions among them.

The criteria developed for the evaluation of effectiveness namely LEI and TEI, are generic enough to be computed for each case study and model and for each dimension (environmental, economic and social). They provide straightforward interpretation of model results both compared to management targets and the current situation. The comparison with the baseline scenario required by the IA guidelines was not made explicit but could easily be achieved by replacing the "current state" value by the value obtained in the baseline scenario in the computation of the criteria. A limit was that comparison between TEI and LEI (obtained for different targets and model outcomes) was not possible because calculated in different ways. TEI and LEI were further summarised using a very visual color code. However, the drawback is that summarising each dimension using only one variable can be difficult where it is known that more than one objective co-exists within a dimension, possibly requiring some ad hoc weighting procedures for these objectives, especially, in multi-fleet and multi-species fisheries.

\footnotetext{
${ }^{5}$ https://www.ices.dk/community/Documents/Advice/Acronyms_and_terminology.pdf
} 
The evaluation of efficiency revealed to be difficult in the context of this study in cases that required the estimation of management costs and social benefits which are not readily available and modelled. The net present value of the profit of the fishery was used as a proxy, which was computable by all models but restricted the significance of the criteria. An essential improvement of the method could be to better define the main management costs to include in the analysis.

A SIA, as any IA process ideally includes an evaluation of the robustness of the diagnostic. Here the influence of external factors was assessed on the achievement of management goals using a scenario approach that was very straightforward to interpret. On the other hand, the amount of results to be analysed increases rapidly with the potential combinations of risk scenarios while it is hardly possible to summarise such a variation with a single value from the risk analysis. Here such risk analyses were not considered. The computation of sensitivity indices is also an option and requires the building of a statistically appropriate design of simulations [58]. Only robustness to external factors was considered while the quantitative nature of mathematical models should not hide their inherent uncertainty.

A synthesis of the main challenges, difficulties and solutions identified when implementing the SIA in the different case studies addressed is reported in Table 6.

\section{Table 6 here}

\section{Conclusions}

The European Union defines Impact Assessments (IA) as a strategic instrument for policy integration and sustainability. The implementation allows managers to decide on policy options with background information on advantages and disadvantages of the respective options.

This paper has provided, by reporting on the results of the SOCIOEC project and implemented case studies, the main steps to follow for a proper implementation of a SIA in fishery management, in line with the EU formal requirement [1], as well as the main strengths and weaknesses encountered along the process. What makes fisheries management so difficult and an important weakness in the SIA process, most of the time, is the existence of conflicting objectives. All conflicts need to be identified and, through a combination of use of the best available scientific and stakeholder's involvement in the overall process, "these conflicts should be reconciled into a set of operational objectives that can realistically be obtained from the fishery" [28]. The work carried out by authors for this paper faced the coherence issue with a multidisciplinary approach with different dimensions (environmental, economic and social), trying to develop a "qualitative" coherence indicator, mainly based on effectiveness indicators and which represents the limitation of the necessary trade-offs. Future SIA improvements should consider the way of producing a more balanced (among dimensions) integrated, quantitative coherence indicator. Indeed, the issue of substitutability or compensability across dimensions remains delicate and unsolved [77].

The main strength of the SIA is to incorporate "soft" (i.e. qualitative) data, obtained by interviewing and collecting information from different stakeholders into the first steps of the impact analysis process. Such incorporation is rarely done in the current impact assessments.

An important improvement in the SIA applied to fishery management in the present study is the use of effectiveness indicators, able to quantify the ability of the management instruments to produce improvements from the current situation (baseline scenario) and in achieving targets, both Target Reference Points and Limit Reference Points. Target Effectiveness Indicator and Limit Effectiveness Indicator were further summarised using a very visual colour code. However, methods have still to be found in order to weight or prioritize conflicting objectives within a given dimension.

For the efficiency evaluation, the authors focused only on the private sector (fisheries) using the net present value of the profit of different fisheries addressed. An essential and future improvement of the method could be to better define which are the main management costs to include in the analysis, being them essential for policy makers to take the best possible decision. It likely requires the estimation of management costs and social benefits, which are hardly available and modelled. In general, public cost are only available at national level without disaggregation at fisheries and/or fleets level. Social benefits are not usually assessed at any level.

The acceptability evaluation is crucial for incorporating the "soft" data with the aim of enhancing a proper policy implementation. The acceptability evaluation is, indeed, obtained by interviewing the main addresses of the policy options under evaluations (i.e. fishermen and, to some extent, controllers) and collecting their feedback on the acceptance of the new options proposed. This will ensure a better compliance and, in that sense, this can be considered, for sure, a SIA improvement for policy development. Further refinements on this aspect could focus on the quantification of acceptability.

An important finding of the work carried out across case studies is the crucial role, for a policy's success, of the coherence of the policy option meant as a balanced achievement of objectives, trying to avoid, as much as possible, trade-off across the three dimensions.

The aim of the authors was to test how a change in the standard methodology for IA applied to fishery management may improve the evaluation procedures of fishery management options and or management plans. By applying the SIA to different fishery case studies, authors have been able to conclude that the combination of quantitative and qualitative approaches is helpful when setting the scene, by making the modeller aware of a variety of stakeholder's views and so allowing the qualitative inputs to be incorporated in the modelling process and identifying drivers of actors' behaviour. 
There is a requirement for the European Commission to provide SIA for every policy proposal. However, not every aspect of a policy decision are/can be analysed under the IA scheme. As the case studies show there are huge differences in availability of data, necessary time and resources. The EC requests IA basically for policy proposal covering large fisheries or complex policy proposal at least on a regional seas level (e.g. landing obligation, basic regulation, technical measures). No IA has been, in particular, carried out so far to elaborate effects on the small-scale fishing sector - this requires a substantial effort for data collection. It is, therefore, necessary in the future to address the special conditions of small - scale fisheries (especially also in the Mediterranean) and allow more effort to be spend to prepare the background information for SIA.

\section{Acknowledgements}

The research leading to these results received funding from the European Union's Seventh Framework Programme (FP7/2007-2013) under grant agreement $n^{\circ}$ 289192. Authors would like to thank Clara Ulrich and the anonymous reviewers for their valuable comments that contributed greatly to improving previous versions of this work. C. D. Maravelias's contribution to this work was exclusively completed while at the Hellenic Centre for Marine Research and this article in no way expresses his current employer position (i.e. European Commission) nor anticipates its future policy in the area.

\section{References}

[1] EC, 2009. Impact assessment guidelines. Brussels. SEC (2009) 92.

[2] COM(2015) 215 final\} \{SWD(2015) 110 final . COMMISSION STAFF WORKING DOCUMENT Better Regulation Guidelines, Strasbourg, 19.05.2015.

[3] Jacob, K. et al., 2008. Improving the Practice of Impact Assessment, EVIA, Berlin.

[4] OECD, 2010. Guidance on Sustainability Impact Assessment.

[5] STECF, 2010. Report of the STECF Development of Protocols for Multi-Annual Plan Impact Assessments, Hamburg. EUR $24368 \mathrm{EN}-2010$.

[6] IVM, Institute for Environmental Studies, SustainabilityA-Test project, Final reports, Amsterdam, 2006.

[7] Andersen, P., Andersen, J.L. and Mardle, S. 2014. What's going to happen with the CFP Reform discard policy? In: Proceedings of the International Institute of Fisheries Economics and Trade Conference 2014, Brisbane, Australia.

[8] Morgan D. 1988. Focus Groups as Qualitative Research. Sage Publications, London: 85p.

[9] Krueger, R. 1998. Focus Group Kit. Vol. 6 Analysing \& Reporting Focus Group Results. Sage Publications, London: 139 p.

[10] Pearce, D., Atkinson, G. and Mourato, S. 2006. Cost-benefit Analysis and the Environment. Recent Developments. OECD Paris: Organisation for Economic Co-operation and Development, $315 \mathrm{pp}$.

[11] Pollnac R, Abbott-Jamieson., Smith., Miller., Clay., Oles. (2006) Toward a model for fisheries social impact assessment. Marine Fisheries Review.

[12] EC. 2013. Regulation (EU) No. 1380/2013 on the Common Fisheries

[13] COM, 2009. 163 final. GREEN PAPER Reform of the Common Fisheries Policy 28 pp.

[14] SOCIOEC Deliverable D2.1 Definition of high-level EU-wide fisheries sustainability objectives. Downloadable from http://www.socioec.eu/outputs/socioec-deliverables

[15] Murillas-Maza, A., and Andrés, M. (2016). Providing incentives for fishermen through rights-based co-management systems. An impact-assessment on Basque fisheries. Marine Policy 70, 128-136.

[16] Le Floc'h, P., Murillas, A., Aranda, M., Daurès, F., Fitzpatrick, F., Guyader, O., Hatcher, A., Macher, C., Marchal, P. 2015. The regional management of fisheries in European Western Waters. Marine Policy 51(2015) 375-384

[17] FAO, 1999. Indicators for sustainable development of marine capture fisheries, FAO Technical Guidelines for Responsible Fisheries, No, 8, Rome. 
[18] OECD, 2002. Fisheries Sustainability Indicators: The OECD experience. Paris.

[19] BEMTOOL FINAL REPORT. DELIVERABLE D10. BEMTOOL - Bio-Economic Modelling TOOLs. FINAL REPORT. February 2013. 46 pp.

[20] FISHRENT, Bio -economic simulation and optimisation model for fisheries, LEI report 2011-024; May 2011. Project code 2231763000. LEI, part of Wageningen UR, The Hague.

[21] Studies in the Field of the CFP and Maritime Affairs No. FISH/2006/09. Lot 4: Impact assessment studies related to the CFP. Available at https://ec.europa.eu/fisheries/sites/fisheries/files/docs/body/report_en.pdf.

[22] Rochet, M.-J.; Trenkel, V.M, (2003). Which community indicators can measure the impact of fishing? A review and proposals. Canadian Journal of Fisheries and Aquatic Sciences. 60(1): 86-99. ISSN 0706-652X

[23] Rice J C. and MJ Rochet, (2005). A framework for selecting a suite of indicators for fisheries management. ICES Journal of Marine Science, 62: $516 \mathrm{e} 527$ (2005).

[24] Caddy, J.F. and Mahon, R,(1995). Reference points for fisheries management, FAO Fisheries. Technical Papers, 347.

[25] Prellezo, R., P. Accadia, J. L. Andersen, B.S. Andersen, E. Buisman, A. Little, J. R. Nielsen, J.J. Poos, J. Powell, and C. Röckmann. 2012. A review of EU bio-economic models for fisheries. The value of a diversity of models. Marine Policy 36 (2): $423-$ 431. doi:10.1016/j.marpol.2011.08.003.

[26] Nielsen J.R., Thunberg E., Holland D. S., et al. 2017. Integrated ecological-economic fisheries models - Evaluation, review and challenges for implementation. Fish and Fisheries 2017, 00:1-29, https://doi.org/10.1111/faf.12232

[27] SOCIOEC, 2015: Deliverable 5.6 - Rating (ex ranking) management measures at CS level. Downloadable from http://www.socioec.eu/outputs/socioec-deliverables.

[28] Cochrane K.L. and Garcia, S., 2009. A fishery manager's guidebook. Second edition, FAO and Wiley-Blackwell.

[29] De Young, C.; Charles, A.; Hjort, A. Human dimensions of the ecosystem approach to fisheries: an overview of context, concepts, tools and methods. FAO Fisheries Technical Paper. No. 489. Rome, FAO. 2008. 152p

[30] Gambino, M., L. Malvarosa, V. Placenti. 2003. Fishery regulation, perceptions and compliance: The fishermen responses. Paper available on-line at

//www.researchgate.net/publication/228287369_Fishery_Regulation_Perceptions_and_Compliance_The_Fishermen_Responses

[31] SOCIOEC, 2014: Deliverable 5.4 - Methodology of quantitative analysis. Downloadable from http://www.socioec.eu/outputs/socioec-deliverables

[32] IUCN 2016. The IUCN Red List of Threatened Species Phocoena phocoena (Baltic Sea subpopulation). Hammond, P.S., Bearzi, G., Bjørge, A., Forney, K.A., Karczmarski, L., Kasuya, T., Perrin, W., Scott, M.D., Wang, J.Y., Wells, R.S. \& Wilson, B. 2016. 2016: e.T17031A98831650. (Last retrieved on October 21st 2016)

[33] Sonntag, N., Schwemmer, H., Fock, H.O., Bellebaum, J., and Garthe, S. 2012. Seabirds, set-nets, and conservation management: assessment of conflict potential and vulnerability of birds to bycatch in gillnets. - ICES Journal of Marine Science, 69: 578-589.

[34] EEC, 1992. Council Directive 92 / 43 / EEC of 21 May 1992 on the conservation of natural habitats and of wild fauna and flora.

[35] EC, 2004. Regulation (EC) No 812/2004 of 26 April 2004 laying down measures concerning incidental catches of cetaceans in fisheries and amending Regulation (EC) No 88/98.

[36] Melur, 2013 Freiwillige Vereinbarung zum Schutz von Schweinswalen und tauchenden Meeresenten Zwischen dem Landesfischereiverband Schleswig-Holstein, dem ischereischutzverband Schleswig-Holstein, dem Ostsee Info-Center Eckernförde (OIC, Betreiber UTS e.V.), und dem Ministerium für Energiewende, Landwirtschaft, Umwelt und ländliche Räume des Landes Schleswig-Holstein (MELUR). Eckenförde December 17th 2013.

[37] EC. 2013. Proposal for a directive of the European parliament and of the council establishing a framework for maritime spatial planning and integrated coastal management. $\operatorname{COM}(2013) 133$ final.

[38] Francois Bastardie, J. Rasmus Nielsen, O. R. Eigaard, H. O. Fock, P. Jonsson, V. Bartolino; Competition for marine space: modelling the Baltic Sea fisheries and effort displacement under spatial restrictions. ICES J Mar Sci 2015; 72 (3): 824-840. doi: 10.1093/icesjms/fsu215 
[39] de Vos, B. I., Döring, R., Aranda, M., Buisman, F. C., Frangoudes, K., Goti, L., Macher, C., Maravelias, C. D., Murillas-Maza, A., van der Valk, O. and Vasilakopoulos, P. (2016) New modes of fisheries governance: Implementation of the landing obligation in four European countries. Marine Policy, 64, pp. 1-8.

[40] Buisman, F. C., Oostenbrugge, J. A. E. v. and Beukers, R. (2013) Economische effecten van een aanlandplicht voor de Nederlandse visserij. Den Haag: LEI Wageningen UR http://edepot.wur.nl/283011

[41] Bartelings, H., Hamon, K. G., Berkenhagen, J. \& Buisman, F. C. 2015. Bio-economic modelling for marine spatial planning application in North Sea shrimp and flatfish fisheries. Environmental Modelling \& Software, 74, 156-172.

[42] Maravelias CD, Maynou, F, \& Pantazi M. 2014. Fisheries management scenarios; Trade-offs between economic and biological objectives. Fisheries Management and Ecology Article first published online: 30 APR 2014 | DOI: 10.1111/fme.12060. 21(3):186195.

[43] Lehuta, Sigrid, Youen Vermard, and Marchal, Paul. "A Spatial Model of the Mixed Demersal Fisheries in the Eastern Channel." In Marine Productivity: Perturbations and Resilience of Socio-Ecosystems. Proc. 15th French-Japan. Oceanogr. Symposium, 187-95. H.-J. Ceccaldi et al., 2015.

[44] STECF - Assessment of Mediterranean Sea stocks - part 1 (STECF-14-17)

[45] STECF - Mediterranean Assessments part 2 (STECF-15-06)

[46] STECF - Mediterranean assessments part 1 (STECF-15-18)

[47] D7.3 ECOFISHMAN Report on simulated "in situ” pilot tests of RFMS with selected stakeholders, 2014. Downloadable from http://ecofishman.eu/deliverables/

[48] Malvarosa L., Accadia P. ,Sabatella R. F., Sala A., Virgili M., Lucchetti A. 2014. Individual transferable effort quota in the Mediterranean demersal trawler fishery. Impact assessment evaluation of a possible future application, Poster presented at the Second Symposium on Fishery-Dependent Information, FAO Headquarters, Rome (IT), February 2014.

[49] SOCIOEC 2014: Deliverable 5.4 - Methodology of quantitative analysis. Downloadable from http://www.socioec.eu/images/SOCIOEC/Media_Centre/Deliverables/SOCIOEC\%20D\%205.4.pdf

[50] Grafton, R.Q., 1996. Individual transferable quotas: theory and practice. Rev. FishBiol. Fish. 6 (1), 5-20.

[51] Grainger, C.A., Costello, C., 2015. Distributional effects of the transition to property rights for a common-pool resource. Mar. Res. Econ. 31 (1), 1-26.

[52] COM, 2011. Proposal for a regulation of the parliament and the council on the Common Fisheries Policy. European Commission 425pp.

[53] FAO, 2003. Fisheries management. 2.The ecosystem approach to fisheries. FAO Technical Guidelines for Responsible Fisheries-No. 4-Supplement 2.

[54] EC, 2010. Synthesis of the Consultation on the Reform of the Common Fisheries Policy Commission Staff Working Document. SEC(2010)408Final, Available online at http://ec.europa.eu/fisheries/reform/sec(2010)0428en.pdf.

[55] EU, 2013. Regulation (EU) No 1380/2013 of the European Parliament and of the Council of 11 December 2013 on the Common Fisheries Policy, amending Council Regulations (EC) No 1954/2003 and (EC) No 1224/2009 and repealing Council Regulations (EC) No 2371/2002 and (EC) No 639/2004 and Council Decision 2004/585/EC Official Journal of the European Union

[56] Larabi Z., O. Guyader, C. Macher, F. Daurès, 2013. Quota management in a context of non-transferability of fishing rights: The French case study. Ocean \& Coastal Management 84:13-22·November 2013

[57] Gouvernement Français, 2009. Mémorandum français relatif à la réforme de la politique commune de la pêche. Paris.

[58] Merzereaud Mathieu, Macher Claire, Bertignac Michel, Fresard Marjolaine, Le Grand Christelle, Guyader Olivier, Daures Fabienne, Fifas Spyros (2011). Description of the Impact Assessment bio-economic Model for fisheries management (IAM). https://w3.ifremer.fr/archimer/doc/00067/17808/15337.pdf 
[59] Macher Claire, Merzereaud Mathieu, Le Grand Christelle, Fresard Marjolaine, Bertignac Michel, Fifas Spyros, Guyader Olivier, Biais Gerard, Lissardy Muriel, Jadaud Angelique, Le Corre Gildas, Frangoudes Katia, Daures Fabienne, Van Iseghem Sylvie, Raveau Adriana (2011). Groupe de travail partenarial pour la construction d'outils bio-économiques d'aide à la décision pour l'aménagement des pêcheries. Rapport final. https://w3.ifremer.fr/archimer/doc/00036/14745/12054.pdf

[60] Claire Macher, Michel Bertignac, Olivier Guyader, Katia Frangoudes, Marjolaine Frésard, Christelle Le Grand, Mathieu Merzéréaud, Olivier Thébaud (2018). The role of technical protocols and partnership engagement in developing a decision support framework for fisheries management, Journal of Environmental Management, Volume 223, 2018, Pages 503-516, ISSN 0301-4797, https://doi.org/10.1016/j.jenvman.2018.06.063.

[61] Bellanger, M., Macher, C., Merzéréaud, M., Guyader, O., Le Grand, C. Investigating trade-offs in alternative catch share systems: an individual-based bio-economic model applied to the Bay of Biscay sole fishery (under review in the Canadian Journal of Fisheries and Aquatic Sciences)

[62] Salz P., E. Buisman, H. Frost, P. Accadia, R. Prellezo and K. Soma, FISHRENT: Bioeconomic simulation and optimisation model for fisheries. LEI report 2011-024. ISBN/EAN: 978-90-8615-514-9, 74p.

[63] COM. Proposal for a regulation of the parliament and the council on the Common Fisheries Policy. European Commission COM(2011)425 final. European Commission;2011.

[64] FAO. Fisheries management. 2. The ecosystem approach to fisheries. FAO Technical Guidelines for Responsible Fisheries No. 4 - Supplement 2,URL:〈http://www.fao.org/documents/pub_dett.asp?lang=en\&pub_id=127549); 2003.

[65] Lutchman I, Hoggarth D. Net losses: untying the Gordian knot of fishing overcapacity. Gland, Switzerland and Cambridge, UK:IUCN; 1999.

[66] Clark CW, Munro GR. The problem of overcapacity. Bull Mar Sci 2002; 11:473-83.

[67]. Asche F, Eggert H, Gudmundsson E, Hoff A, Pascoe S. Fisher's behavior with individual vessel quotas—over-capacity and potential rent: five case studies. Mar Policy2008;32(6):920-7.

[68] Asche F, Bjørndal MT, Bjørndal T. Development in fleet fishing capacity in rights based fisheries. Mar Policy 2014; 44:166-71.

[69] Newell RG, Sanchirico JN, Kerr S. Fishing quota markets. J Environ Econ Manage 2005;49(3):437-62.

[70] Thøgersen, T, Eigaard OR, Fitzpatrick M, Mardle M, Andersen, JL, Haraldsson, G. Economic gains from introducing international ITQs - The case of the mackerel and herring fisheries in the Northeast Atlantic. Mar Policy 2015; 59:85-93

[71] Eliasen S., Mathiesen C., Andersen S.E., Boom J., Frost H., Hoff A., Hovgaard H., Jørgensen O., Krog C., Nielsen R., Nordberg E. and Vestergaard N., 2008. IMPSEL - Implementering af mere selektive og 47 skånsomme fiskerier. Begreber og internationale erfaringer. IFRO report no. 195. Accessible at http://www.ifro.ku.dk/english/publications/foi_series/foi_reports/.

[72] Hilborn, R. 2007. Managing fisheries is managing people: what has been learned? Fish and Fisheries, 8: 285-296.

\section{[73] www.EFIMAS-project.org}

[74] Nielsen, J.R. and Limborg, M. 2009. Managing fleets and fisheries rather than single stocks - conceptual change in European fisheries management advice. World Fishing 58 (1): 8-9.

[75] Gourguet S., C. Macher, L. Doyen, O. Thébaud, M. Bertignac, O. Guyader. 2013. Managing mixed fisheries for bio-economic viability. Fisheries research. Volume 140, February 2013, Pages 46-62

[76] Lehuta, Sigrid, Stéphanie Mahévas, Pierre Petitgas, and Dominique Pelletier. "Combining Sensitivity and Uncertainty Analysis to Evaluate the Impact of Management Measures with ISIS-Fish: Marine Protected Areas for the Bay of Biscay Anchovy (Engraulis Encrasicolus) Fishery.” ICES Journal of Marine Science: Journal Du Conseil 67, no. 5 (July 1, 2010): 1063-75. doi:10.1093/icesjms/fsq002.

[77] Garmendia, E., R. Prellezo, A. Murillas, M. Escapa, et M. Gallastegui (2010). Weak and strong sustainability assessment in fisheries. Ecological Economics 70, no 1 (15 November 2010): 96-106. doi:10.1016/j.ecolecon.2010.08.001. 


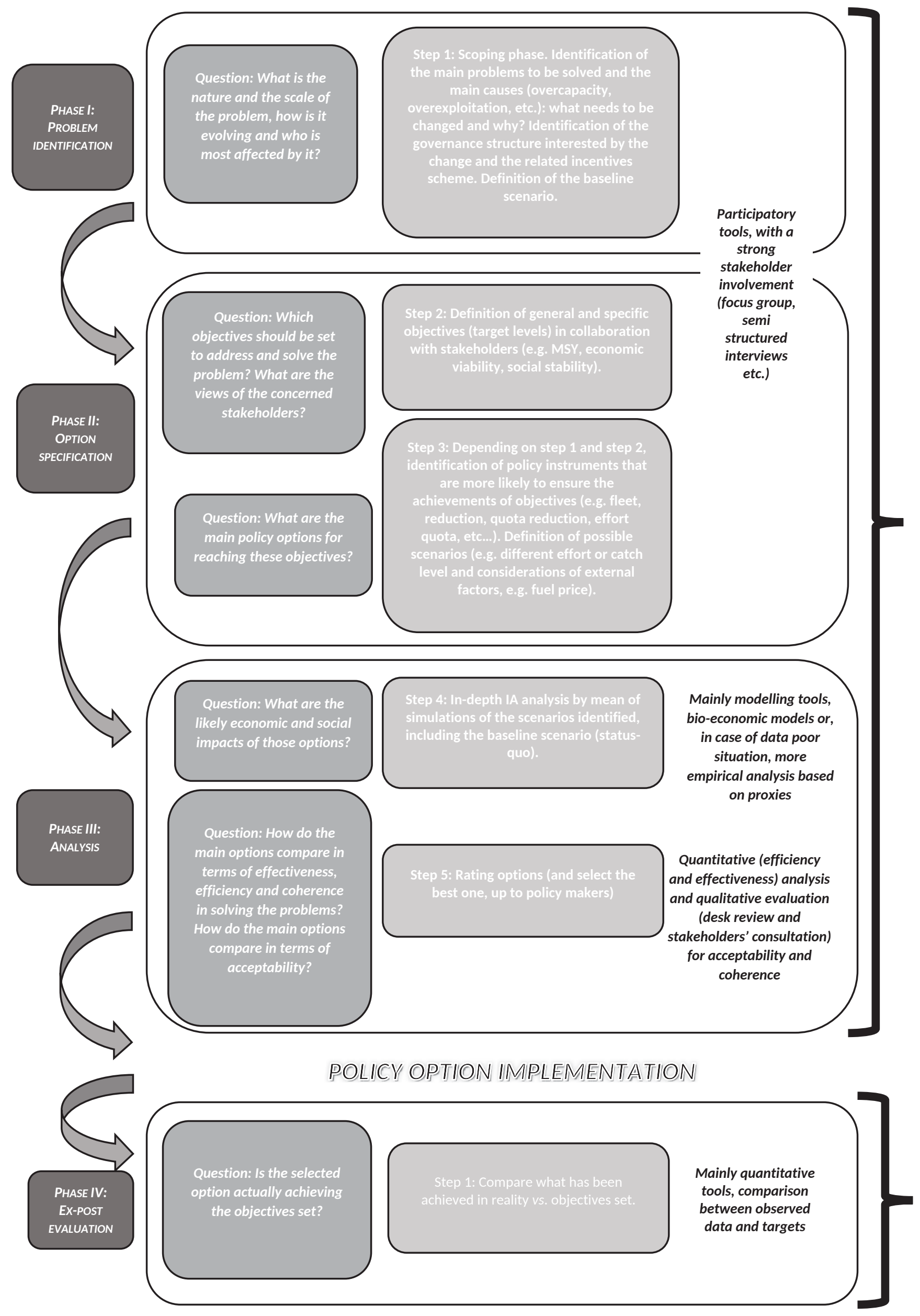




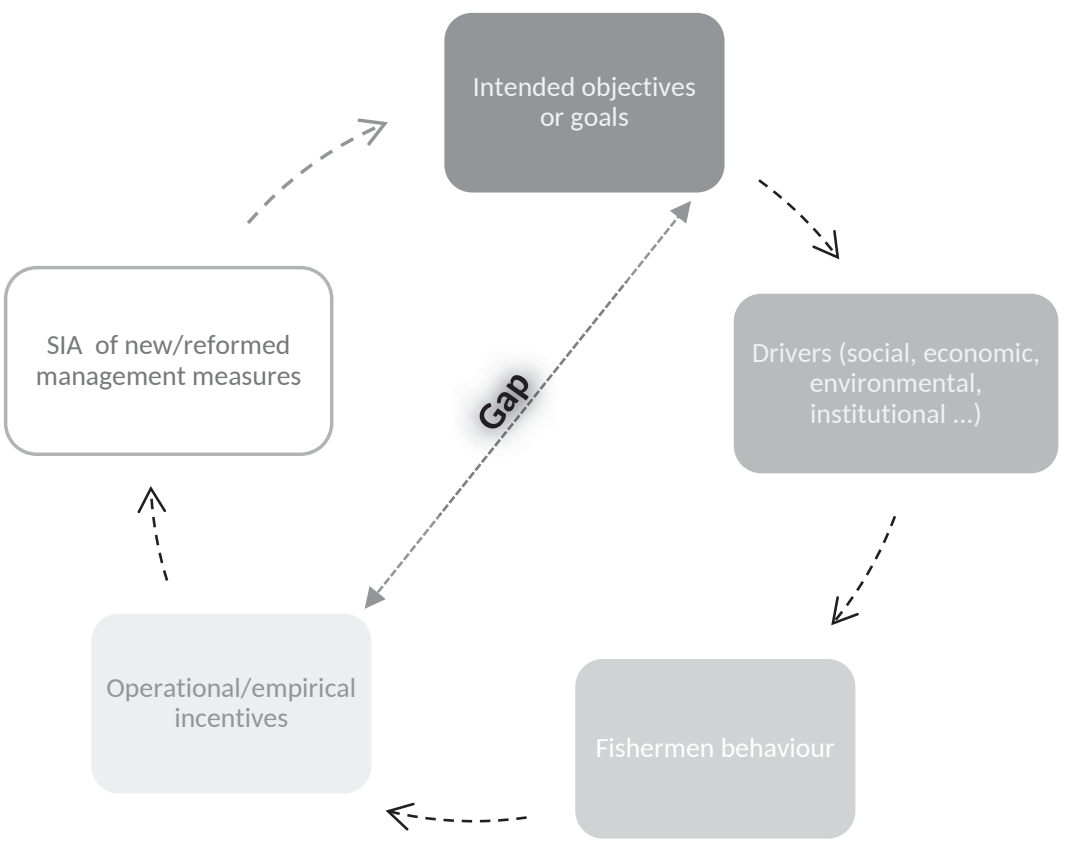


Figure 1 - Phases, key questions and methodologies for a SIA analysis in fishery management

Figure 2 - Relations in a SIA taking into account fishermen behaviour (and co-management processes) 
Table 1 - Example of a synthesis table used for the quantitative analysis for the SIA.

\begin{tabular}{|c|c|c|c|c|c|c|c|}
\hline $\begin{array}{l}\text { Fishery } \\
\text { object of } \\
\text { policy } \\
\text { change }\end{array}$ & $\begin{array}{c}\text { Innovative management } \\
\text { measure to be evaluated (with } \\
\text { main alternatives) }\end{array}$ & $\begin{array}{c}\text { General } \\
\text { objectives }\end{array}$ & $\begin{array}{c}\text { Specific } \\
\text { objectives }\end{array}$ & $\begin{array}{l}\text { Indicators in } \\
\text { relation to the } \\
\text { objectives } \\
\text { (ecological, } \\
\text { economic, social) }\end{array}$ & $\begin{array}{l}\text { Reference } \\
\text { points }\end{array}$ & $\begin{array}{c}\text { Limit } \\
\text { (LRP) or } \\
\text { target } \\
\text { reference } \\
\text { point } \\
\text { (TRP) } \\
\end{array}$ & $\begin{array}{l}\text { Tool/model } \\
\text { used for } \\
\text { simulation }\end{array}$ \\
\hline \multirow{9}{*}{$\begin{array}{l}\text { Demersal } \\
\text { trawler } \\
\text { fishery in } \\
\text { Italian } \\
\text { Northern } \\
\text { Adriatic } \\
\text { (Mediterran } \\
\text { ean Sea, } \\
\text { GSA 17) }\end{array}$} & \multirow{9}{*}{$\begin{array}{l}\text { Effort quota } \\
\text { - } \quad \text { Alternative 0: Status-quo } \\
\text { Alternative 1: Days at sea } \\
\text { at Fmsy (F0.1) for } \\
\text { European hake; No ITE } \\
\text { system } \\
\text { Alternative 2: Days at sea } \\
\text { at } 2012 \text { level; ITE system } \\
\text { (Transferability allowed } \\
\text { among bottom trawlers } \\
\text { over } 12 \mathrm{~m}) \\
\text { Alternative } 3: \text { Days at sea } \\
\text { at Fmsy (F0.1) for } \\
\text { European hake; ITE system } \\
\text { (Transferability allowed } \\
\text { among bottom trawlers } \\
\text { over } 12 \mathrm{~m} \text { ) }\end{array}$} & $\begin{array}{c}\text { Environmental } \\
\text { sustainability }\end{array}$ & $\begin{array}{c}\text { Maximum } \\
\text { Sustainable } \\
\text { Yield (MSY) }\end{array}$ & $\begin{array}{l}\text { Fishing mortality } \\
\text { (F) }\end{array}$ & $\mathrm{F}_{\mathrm{MSY}}$ & TRP/LRP & \multirow{9}{*}{$\begin{array}{l}\text { HDA } 1.2 \\
\text { model }^{1}\end{array}$} \\
\hline & & \multirow{6}{*}{$\begin{array}{l}\text { Economic } \\
\text { sustainability }\end{array}$} & \multirow{4}{*}{$\begin{array}{l}\text { Economic } \\
\text { viability }\end{array}$} & \multirow[b]{2}{*}{ Profit } & $>=0$ & LRP & \\
\hline & & & & & $\begin{array}{l}\text { Average profit } \\
\text { over the last } x \\
\text { years } \\
\end{array}$ & TRP & \\
\hline & & & & \multirow[b]{2}{*}{$\begin{array}{c}\text { Profit/Revenues } \\
\%\end{array}$} & $>=0 \%$ & LRP & \\
\hline & & & & & $\begin{array}{c}\text { Average } \\
\text { Profit/Revenues } \\
\% \text { over the last } x \\
\text { years } \\
\end{array}$ & TRP & \\
\hline & & & Sector & $\begin{array}{c}\text { RoFTA (Return } \\
\text { on Fixed }\end{array}$ & $\begin{array}{l}\text { s=long-term } \\
\text { government } \\
\text { bonds rate }\end{array}$ & LRP & \\
\hline & & & attractıveness & Tangible Assets) & $\begin{array}{c}\text { Average RoFTA } \\
\text { over the last } x \\
\text { years }\end{array}$ & TRP & \\
\hline & & \multirow{2}{*}{$\begin{array}{c}\text { Social } \\
\text { sustainability }\end{array}$} & \multirow{2}{*}{$\begin{array}{l}\text { Social } \\
\text { stability }\end{array}$} & \multirow{2}{*}{$\begin{array}{l}\text { Average crew } \\
\text { remuneration }\end{array}$} & $>=\underset{\text { wage }}{\operatorname{minimum}}$ & LRP & \\
\hline & & & & & $\begin{array}{l}\text { Average wage } \\
\text { over the last } x \\
\text { years } \\
\end{array}$ & TRP & \\
\hline
\end{tabular}

\footnotetext{
${ }^{1}$ For details on the model see Table 4.
} 
Table 1-Scenarios matrix for a SIA

\begin{tabular}{llllll}
\hline Scenarios & External factor $\mathbf{0}$ & External factor 1 & External factor 2 & $\ldots \ldots$ & External factor $\mathbf{n}$ \\
\hline Status Quo & sub-scenario 0.0 & sub-scenario 0.1 & sub-scenario 0.3 & $\ldots \ldots$ & sub-scenario $0 . n$ \\
Alternative 1 & sub-scenario 1.0 & $\ldots \ldots$ & $\ldots \ldots$ & $\ldots \ldots$. & sub-scenario $1 . n$ \\
Alternative 2 & $\ldots \ldots$ & $\ldots \ldots$ & $\ldots \ldots$ & $\ldots \ldots$ & sub-scenario $2 . n$ \\
$\ldots \ldots$ & $\ldots \ldots$ & $\ldots \ldots$ & $\ldots \ldots$ & $\ldots \ldots$ & $\ldots \ldots$ \\
Alternative $m$ & sub-scenario $m .0$ & sub-scenario $m .1$ & sub-scenario $m .2$ & $\ldots \ldots$ & sub-scenario $m . n$ \\
\hline
\end{tabular}


Table 1 - Hypothetical example of a decision or comparison table for the rating phase in a SIA for fishery management

\begin{tabular}{|c|c|c|c|c|}
\hline $\begin{array}{r}\text { Evaluation } \\
\text { criteria }\end{array}$ & \multirow{2}{*}{ Acceptability } & \multirow{2}{*}{ Effectiveness } & \multirow{2}{*}{ Efficiency } & \multirow{2}{*}{ Coherence } \\
\hline Policy Options & & & & \\
\hline $\begin{array}{l}\text { Management } \\
\text { option 0 } \\
\text { Status Quo }\end{array}$ & $\begin{array}{l}\text { Low compliance } \\
\text { with .............. }\end{array}$ & $\begin{array}{l}\text { Negative environmental/biological } \\
\text { indicators and positive social } \\
\text { indicators. } \\
\text { Far from economic targets but } \\
\text { above the economic minimum } \\
\text { levels. }\end{array}$ & $\begin{array}{l}\text { The NPV of } \\
\text { the profit is } \\
\text { positive. }\end{array}$ & $\begin{array}{l}\text { Balance between economic and } \\
\text { social results but incoherence if } \\
\text { considering } \\
\text { environmental/biological results. }\end{array}$ \\
\hline $\begin{array}{l}\text { Management } \\
\text { option } 1 . \\
\text { External factor } \\
\text { 0. }\end{array}$ & $\begin{array}{l}\text { Improvement of } \\
\text { the compliance } \\
\text { with } \ldots \ldots \ldots \ldots \ldots \ldots\end{array}$ & $\begin{array}{l}\text { Positive social } \\
\text { environmental/biological impacts } \\
\text { but negative impact on the } \\
\text { economic dimension. }\end{array}$ & $\begin{array}{l}\text { Similar NPV } \\
\text { than in the } \\
\text { Status Quo. }\end{array}$ & $\begin{array}{l}\text { Balance between social and } \\
\text { environmental/biological results } \\
\text { but incoherence if considering } \\
\text { economic results. }\end{array}$ \\
\hline
\end{tabular}


Table 1 - Results of the SIA applied to different case studies, by main problems identified and phases.

\begin{tabular}{|c|c|c|c|c|}
\hline $\begin{array}{c}\text { MAIN } \\
\text { PROBLEMS }\end{array}$ & CASE STUDIES & PHASE I & PHASE II & PHASE III \\
\hline $\begin{array}{l}\text { A .Gillnet fishing } \\
\text { impact on protected } \\
\text { species }\end{array}$ & $\begin{array}{c}\text { Fehmarn Belt small scale } \\
\text { fishery }\end{array}$ & $\begin{array}{l}\text { Gillnet fishing is one of the causes of harbour } \\
\text { porpoises and diving seabirds' mortality in the } \\
\text { Baltic Sea, due to entrapment in the bottom set } \\
\text { nets ([32], [33]). }\end{array}$ & $\begin{array}{l}\text { To protect affected species (e.g. harbour } \\
\text { porpoises and diving seabirds) from gillnet } \\
\text { fishing, both conservation and fisheries } \\
\text { management measures are contemplated } \\
\text { under the Fauna, Flora and Habitats } \\
\text { Directive (FFH regulation) and the CFP } \\
\text { ([34], [35]) in the Baltic Fehmarn island } \\
\text { small scale fishery. After strong oppositions, } \\
\text { a stakeholder consultation took place and a } \\
\text { voluntary agreement [36] to reduce the effort } \\
\text { during two months in summer and closing } \\
\text { the fishery up to three and a half months in } \\
\text { winter was signed, stating as objectives the } \\
\text { protection of the endangered species and } \\
\text { maintenance of the fishing communities. }\end{array}$ & $\begin{array}{l}\text { Results of the impacts deriving from the reduction of the fishing } \\
\text { effort to face problems generated by gillnet fishing were provided } \\
\text { by a simple "what if analysis". A calculation of the reduction in } \\
\text { revenues that the measures would result in when applied to the latest } \\
\text { economic data available showed strong economic losses. Further } \\
\text { results from the qualitative data collection showed that more } \\
\text { realistic objectives for the agreement would be the improvement of } \\
\text { the cooperation between fishers, scientists and management so that } \\
\text { fishers contribute effectively with data that can be used for the } \\
\text { assessment of the critically endangered harbour porpoise stock. } \\
\text { Management could also, through a knowledge building dialogue } \\
\text { with fishers and scientists, establish adequate adaptive measures } \\
\text { (including the possibility of compensations) when implementing } \\
\text { closures, that would contribute to the objective of the maintenance } \\
\text { of the fishing community. }\end{array}$ \\
\hline $\begin{array}{l}\text { B. Maritime spatial } \\
\text { planning }\end{array}$ & $\begin{array}{l}\text { Western Baltic large-scale } \\
\text { fisheries }\end{array}$ & $\begin{array}{l}\text { Area closures according to existing and } \\
\text { planned windmill farms and Natura } 2000 \text { areas } \\
\text { were evaluated for Western Baltic large scale } \\
\text { commercial fishery for cod, herring and sprat. } \\
\text { Maritime spatial planning [37] and fishery } \\
\text { management [12] may generate extra costs for } \\
\text { fisheries in the short term by constraining } \\
\text { fishers' activity through the establishment of } \\
\text { conservation areas, however, it may generate } \\
\text { an economic value for the fisheries in the long- } \\
\text { term. Scientists conduct such risk analysis } \\
\text { within the framework of science projects } \\
\text { supporting the new EU integrative policy } \\
\text { where MSP defines principles that call for } \\
\text { scientific support for the inventory, draft } \\
\text { development, and negotiation phases of MSP } \\
\text { processes. }\end{array}$ & $\begin{array}{l}\text { The maritime spatial planning application } \\
\text { and the impact of area closures on Western } \\
\text { Baltic large scale commercial fishery for } \\
\text { cod, herring and sprat is analysed to identify } \\
\text { the parts of the fisheries affected by the } \\
\text { spatial restriction. The investigation is based } \\
\text { on several previous academic studies on the } \\
\text { Baltic Sea ecosystems, which enable the } \\
\text { scientists to come with supportive } \\
\text { knowledge for identifying relevant entities to } \\
\text { look at in the scenario evaluation. The range } \\
\text { of likely micro-decision-making in operating } \\
\text { the fishing in different fisheries situations } \\
\text { has been based on a questionnaire survey to } \\
\text { fishers, also including feedbacks from the } \\
\text { fishermen associations on the questionnaire } \\
\text { itself. }\end{array}$ & $\begin{array}{l}\text { The outcomes of alternative scenarios for spatial effort displacement } \\
\text { have been exemplified in the spatial DISPLACE model [38] by } \\
\text { evaluating a fisher's abilities to adapt to spatial plans under various } \\
\text { constraints. In terms of effectiveness, results provide evidence that } \\
\text { spatial restrictions affecting the interlinked spatial, technical, and } \\
\text { biological dynamics of vessels and stocks in the scenarios result in } \\
\text { stable profits, which compensate for the additional costs from effort } \\
\text { displacement and release pressure on the fish stocks. Tested spatial } \\
\text { restrictions contribute to enhancing the system to stay within the } \\
\text { predefined biological reference points. By contrast, the effectiveness } \\
\text { was lowered when fuel costs increased from vessels redirecting their } \\
\text { effort on closer areas and other biological components, or when } \\
\text { stocks where less productive than expected in the baseline situation. } \\
\text { The effort is further redirected away from sensitive benthic habitats, } \\
\text { enhancing the ecological positive effects. The energy efficiency of } \\
\text { some of the vessels, however, is strongly reduced with the new } \\
\text { zonation, and some of the vessels suffer decreased profits which is } \\
\text { especially the case for smaller vessels having less possibility for } \\
\text { reallocating their effort compared to the larger vessels given the } \\
\text { closures. Feed-back on the results from Baltic Sea Advisory Council } \\
\text { (BSAC) focus group consultations were that the level of complexity } \\
\text { and detail in the approach is adequate to account for relevant short- } \\
\text { to medium term effects within a reasonable time frame given } \\
\text { potential externalities (fish price dynamics, etc.). }\end{array}$ \\
\hline
\end{tabular}




\begin{tabular}{|c|c|c|c|c|}
\hline $\begin{array}{c}\text { MAIN } \\
\text { PROBLEMS }\end{array}$ & CASE STUDIES & PHASE I & PHASE II & PHASE III \\
\hline \multirow[b]{2}{*}{$\begin{array}{c}\text { C. Landing } \\
\text { Obligation (LO) }\end{array}$} & Flatfish fishery & $\begin{array}{l}\text { The new CFP discard ban (landing obligation, } \\
\text { LO) is a key policy option to address. Its } \\
\text { effects have been analyzed for the North Sea } \\
\text { beam trawl fishery for flatfish, for which } \\
\text { substantial discarding (up to } 55 \% \text { of the catch) } \\
\text { happens. The target species is sole, Solea solea, } \\
\text { and the main bycatch or unwanted catch is } \\
\text { plaice. The stakeholders believe that a large } \\
\text { proportion of the unwanted catch survives } \\
\text { being thrown back to sea and are therefore } \\
\text { against the landing obligation [39]. }\end{array}$ & $\begin{array}{l}\text { The fishing industry in the North Sea flatfish } \\
\text { fishery (mainly Dutch) was strongly against } \\
\text { the implementation of the LO and has } \\
\text { worked on obtaining exemptions (based on } \\
\text { economic feasibility and high survivability). } \\
\text { Because of their mistrust in the process that } \\
\text { led to the LO, it was very difficult to get } \\
\text { them involved in discussions around its } \\
\text { implementation (especially in the name of a } \\
\text { "European" project). The information } \\
\text { collected and used in phase III came, indeed, } \\
\text { from another national project [40]. The } \\
\text { implementation of the LO started in January } \\
\text { 2016. }\end{array}$ & $\begin{array}{l}\text { Quota trading and LO for the North Sea Flatfish fishery were } \\
\text { simulated in the spatial model SIMFISH [41]. Because the fishery } \\
\text { was already doing better in terms of ecological sustainability, all } \\
\text { management options (including the status quo) reached the } \\
\text { environmental/biological objectives for plaice and showed great } \\
\text { improvement for sole. Despite a reduction of profitability with the } \\
\text { LO, the fleets remained viable and attractive. The analysis was } \\
\text { finalized by the rating phase: while all scenarios were positively } \\
\text { rated in terms of effectiveness, coherence and efficiency, the LO } \\
\text { was not acceptable for the sector. In a fishery that targets a highly } \\
\text { valuable fish (sole) but has to discard the juveniles of less valuable } \\
\text { plaice or adults of non-commercial species, having the constraint to } \\
\text { land all the catch is considered not acceptable. }\end{array}$ \\
\hline & $\begin{array}{l}\text { Greek Aegean demersal } \\
\text { fishery }\end{array}$ & $\begin{array}{l}\text { Fishermen were aware of the new landing } \\
\text { obligation (LO), i.e. CFP discard ban. Hake is } \\
\text { the main commercially important species and is } \\
\text { currently overexploited. The organized } \\
\text { meetings with stakeholders allowed the debate } \\
\text { on the existing management system and the } \\
\text { upcoming LO to take place. Stakeholders } \\
\text { enabled the identification of the key issues to } \\
\text { be considered in the SIA. In addition, the } \\
\text { effects of a potential change in the fishing } \\
\text { operations of the demersal trawl fleet in } \\
\text { Thermaikos gulf (Aegean Sea, GSA 22) as a } \\
\text { consequence of LO has been considered. }\end{array}$ & $\begin{array}{l}\text { The effects of a potential change in the } \\
\text { fishing operations of the demersal trawl fleet } \\
\text { in Thermaikos gulf were examined with the } \\
\text { aim to reduce both unwanted catches of } \\
\text { undersized fish and fleet overcapacity. In } \\
\text { particular, a potential closure of hake } \\
\text { nurseries to trawling in addition to an effort } \\
\text { reduction and displacement scheme was } \\
\text { proposed. }\end{array}$ & $\begin{array}{l}\text { The LO application was also simulated in the Mediterranean Greek } \\
\text { Aegean Sea demersal fishery using the MEFISTO bio-economic } \\
\text { model [42]. The SIA was carried out in two parts, the second one } \\
\text { being required from an adaptation based on stakeholders' feedback } \\
\text { which resulted in additional model runs investigating the effects of } \\
\text { incomplete fishermen compliance to the closure, spatio-temporal } \\
\text { shifts in effort, a reduction in fishing days and limited } \\
\text { decommission of trawlers. The main significant result produced } \\
\text { under the modelling analysis was that in all scenarios where a full or } \\
\text { a partial protection of hake juveniles was simulated, catches and } \\
\text { profits of both the coastal and the trawler fleet segments increased } \\
\text { in just two years after the implementation of the new management } \\
\text { measures. The stock size of hake also significantly increased in all } \\
\text { scenarios. Even when the simulated effort displacement resulted in } \\
\text { increased catches of non-juveniles, the benefits for profits, catches } \\
\text { and stock status from allowing more fish to spawn-at-least-once and } \\
\text { fulfil their growth potential were still evident. However, in all } \\
\text { scenarios a decrease in both catches and profits of the trawler fleet } \\
\text { was observed in the first year of implementing the closure of hake } \\
\text { nurseries to trawling. }\end{array}$ \\
\hline
\end{tabular}




\begin{tabular}{|c|c|c|c|c|}
\hline $\begin{array}{c}\text { MAIN } \\
\text { PROBLEMS }\end{array}$ & CASE STUDIES & PHASE I & PHASE II & PHASE III \\
\hline & $\begin{array}{c}\text { Eastern English Channel } \\
\text { mixed fishery }\end{array}$ & $\begin{array}{l}\text { The Eastern English Channel mixed demersal } \\
\text { fishery (carried out by French netters) faced } \\
\text { limitations of sole quota and high discard rates } \\
\text { that made fishermen worried about the possible } \\
\text { implementation of the landing obligation. } \\
\text { Rising conflicts with foreign fleets about the } \\
\text { red mullet fishery that is not under quota yet, } \\
\text { made it clear that there is a need to investigate } \\
\text { the impacts of changes in the current } \\
\text { management of these species and particularly } \\
\text { account for the mixed nature of the catch. Key } \\
\text { problems identified and debated with } \\
\text { stakeholders in different fora were taken into } \\
\text { account for the application of the SIA on the } \\
\text { Eastern English Channel mixed fishery. }\end{array}$ & $\begin{array}{l}\text { In the context of the Eastern English Channel } \\
\text { mixed fishery a management plan decided } \\
\text { for sole, based on a transition to MSY in } 5 \\
\text { years, allows objectives to be reached only if } \\
\text { the LO is implemented. It was difficult to } \\
\text { identify quantitative targets starting from } \\
\text { input from stakeholders, but qualitative } \\
\text { targets were defined using stakeholders' } \\
\text { recommendations. }\end{array}$ & $\begin{array}{l}\text { Simulations for the Eastern English Channel fishery were done } \\
\text { using the ISIS-FISH model [43]. The management plan adopted for } \\
\text { sole, based on a transition to MSY in } 5 \text { years, allows objectives to } \\
\text { be reached only if the LO is implemented. Nevertheless, it is the } \\
\text { most effective of the five Harvest Control Rules (HCR) tested for } \\
\text { sole (which include a Data Limited Stock, DLS, rule based on the } \\
\text { indicator of mean length in the stock). Management for sole also } \\
\text { benefits plaice that is caught simultaneously but the effects on red } \\
\text { mullet vary according to the level of opportunism hypothesized for } \\
\text { fishermen. As for discard reduction, the de-minimis system would } \\
\text { need to be clarified before results can be properly assessed. In terms } \\
\text { of economic performance, effectiveness of measures varies largely } \\
\text { across fleets according to their dependency on sole. However, the } \\
\text { simulations evidenced a good coherence between environmental and } \\
\text { socio-economic objectives in the long term, particularly for the } \\
\text { management strategies that were the most constraining in the short } \\
\text { term, such as the landing obligation. }\end{array}$ \\
\hline D. Overexploitation & $\begin{array}{l}\text { Italian Northern Adriatic } \\
\text { demersal fishery }\end{array}$ & $\begin{array}{l}\text { Overexploitation rates for the main demersal } \\
\text { target species [44, 45, 46] in the Mediterranean } \\
\text { mixed demersal fishery (GSA 17) makes it } \\
\text { clear that there is a need to change the present } \\
\text { management system. The discussion about the } \\
\text { main problem, e.g. overexploitation, benefited } \\
\text { of synergies with other on-going projects, i.e. } \\
\text { Ecofishman ([47], [48]), focusing on the same } \\
\text { fishing area and problem. Meetings with } \\
\text { stakeholders were intended to frame the } \\
\text { problem by showing stock assessment data and } \\
\text { general status of Mediterranean fisheries. } \\
\text { Meeting with stakeholders have given the } \\
\text { opportunity to debate about the current } \\
\text { management system, strengths and limitations } \\
\text { in the Mediterranean area, focusing on GSA17. } \\
\text { Different Stakeholders representing Italian } \\
\text { fishery sector attended the meeting: fisheries } \\
\text { association, NGOs, fishermen, fish market and } \\
\text { fishing industry representatives, scientist from } \\
\text { FAO and research institute and a member of } \\
\text { Member states sharing stocks in GSA } 17 .\end{array}$ & $\begin{array}{l}\text { The problem of high overexploitation } \\
\text { promoted the discussion about the option to } \\
\text { change the present management system in } \\
\text { the Mediterranean mixed fishery in GSA } 17 . \\
\text { Looking at experiences from similar fisheries } \\
\text { the implementation of an effort quota system } \\
\text { (based on Individual Transferable Effort } \\
\text { quota, ITE) has been proposed and discussed } \\
\text { with stakeholders ([47], [48]). }\end{array}$ & $\begin{array}{l}\text { Individual Transferable Effort Quota (ITE) as an alternative } \\
\text { management tool for mixed demersal fishery in GSA } 17 \text { were } \\
\text { simulated through the HDA1.2 model [49]. The achievement of } \\
\text { Fmsy for the main target species, European hake, is fully achieved } \\
\text { by Scenario } 1 \text { (only } 51 \% \text { reduction in days at sea, no ITE), partially } \\
\text { achieved by Scenario } 3 \text { (51\% reduction and ITE) and not achieved } \\
\text { by Status Quo and Scenario } 2 \text { (no reduction in day at sea, ITE). As } \\
\text { for economic and social indicators, the main LRPs have not been } \\
\text { exceeded and the LEI values are equal to } 1 \text { in all scenarios. } \\
\text { However, model outcomes show a better performance of the } \\
\text { Scenarios } 1 \text { and } 3 \text { compared with Status Quo and Scenario } 2 \text {. The } \\
\text { best performance, in efficiency terms (measured by the Net Present } \\
\text { Value, NPV) is registered in the short term (time horizon 2018) by } \\
\text { Status Quo and Scenario } 3 \text { and in the long term (time horizon 2026) } \\
\text { by Scenarios } 1 \text { and Scenario } 3 \text {. The transferability of effort quotas } \\
\text { determines a worsening in efficiency terms in the long term and an } \\
\text { improvement, even if very limited, in the short term. The feedback } \\
\text { from stakeholders has been taken into account presenting them the } \\
\text { results of the first round of simulations. This was extremely } \\
\text { important as the management measure analyzed represents a novelty } \\
\text { for that fishery. }\end{array}$ \\
\hline
\end{tabular}




\begin{tabular}{|c|c|c|c|c|}
\hline $\begin{array}{c}\text { MAIN } \\
\text { PROBLEMS }\end{array}$ & CASE STUDIES & PHASE I & PHASE II & PHASE III \\
\hline \multirow{3}{*}{$\begin{array}{c}\text { E. Overcapacity } \\
\text { (proposal from } \\
\text { CFP of } \\
\text { Transferable } \\
\text { Fishing } \\
\text { Concessions, TFC) }\end{array}$} & Bay of Biscay sole fishery & \multirow{2}{*}{$\begin{array}{l}\text { TFC has been one of the major issues discussed } \\
\text { in the CFP reform [13] and while they are } \\
\text { presented as an efficient management tool to } \\
\text { tackle overcapacity and thus overexploitation, } \\
\text { it was also pointed out as an inequitable tool } \\
\text { leading to concentration of fishing rights ([50], } \\
\text { [51]). A major challenge of the EU Common } \\
\text { Fisheries Policy is the overcapacity of } \\
\text { European fleets [52], which is one barrier } \\
\text { towards economically efficient fisheries [53]. } \\
\text { Pros and cons of TFC compared to alternative } \\
\text { management of quotas were largely discussed } \\
\text { during the process of their adoption. Following } \\
\text { strong positions taken by some Member States } \\
\text { against TFC [54], it was decided to let Member } \\
\text { States decide on their implementation: } \\
\text { "Member States may establish a system of } \\
\text { transferable fishing concessions" [55]. In } \\
\text { France, the law prevents the transferability of } \\
\text { fishing rights and an alternative system of } \\
\text { rights pooling and redistribution has been } \\
\text { developed up to 2006 based on Producer } \\
\text { Organisations (PO) [56]. The Bay of Biscay } \\
\text { sole fishery and the Basque fisheries examples } \\
\text { are provided. }\end{array}$} & $\begin{array}{l}\text { In relation to the overexploitation and } \\
\text { overcapacity problems, the ITQ systems are } \\
\text { proposed in several case studies. While a } \\
\text { consensus against market-based management } \\
\text { was officially admitted by the sector [57] and } \\
\text { the administration in France, interviews with } \\
\text { fishermen conducted in the Bay of Biscay } \\
\text { sole fishery in Western Waters highlighted } \\
\text { more complex positions of the affected } \\
\text { stakeholders. Also existing forms of market } \\
\text { already implemented in the fishery to } \\
\text { circumvent non- transferability are } \\
\text { highlighted in [56]. }\end{array}$ & $\begin{array}{l}\text { For the Bay of Biscay sole fishery, simulations of two alternative } \\
\text { governance systems were performed based on the IAM model ([58], } \\
\text { [59], [60]): i) the current co-management system by PO and ii) an } \\
\text { alternative ITQ. Assessments of the options according to the } \\
\text { different criteria highlighted the economic efficiency of the ITQ } \\
\text { scenarios but also an important trade-off between economic and } \\
\text { social objectives compared to the current co-management system. } \\
\text { While an ITQ system could adjust capacities, it would at the same } \\
\text { time modify the structure of the fleet with potential territorial side- } \\
\text { effects but also potential ecological impacts in this case where } \\
\text { netters effort is replaced by trawling effort [61]. }\end{array}$ \\
\hline & Basque fisheries & & $\begin{array}{l}\text { In 2008, a common-pooling system of } \\
\text { individual transferable quotas for blue-fin } \\
\text { tuna Basque fisheries was introduced under a } \\
\text { fishermen self-management governance of } \\
\text { the common-pooling individual quotas - at } \\
\text { regional level - scheme under the Producer } \\
\text { Organization (PO) umbrella. This fishery } \\
\text { represents un example in which the } \\
\text { stakeholders/fishermen not only provide } \\
\text { knowledge but also, they participate in } \\
\text { making-decision process. Moving from a } \\
\text { previous top-down system. } \\
\text { In relation to the offshore Basque fleet, in } \\
\text { December 2006, a system of ITQs for } \\
\text { vessels over 100 GRT operating in ICES } \\
\text { areas Vb, V, VII and VIIIa,b,d,e.was } \\
\text { established. }\end{array}$ & $\begin{array}{l}\text { Simulations of the Individual Quota system by mean of the } \\
\text { FISHRENT model [62] for the Basque fisheries provides evidence } \\
\text { that the best effectiveness index (LEI, TEI) values occur in the } \\
\text { medium term for almost all dimensions, but in the long term the } \\
\text { status quo (based on a TAC system) achieves better index values for } \\
\text { the majority of dimensions. In the efficiency evaluation, the NPV of } \\
\text { the profit is positive and ITQ is the most efficient management } \\
\text { measure, for any time horizon. It seems to be clear that the } \\
\text { management model based on ITQs (status quo) leads the Basque } \\
\text { trawler segment to achieve a good economic and social } \\
\text { effectiveness values over the long-terms. However, the estimated } \\
\text { effectiveness indexes show a negative change when analysing the } \\
\text { application of LOs (alternative), becoming even worse when } \\
\text { introducing a potential scenario without scrapping subsidies. } \\
\text { The introduction of the common-pooling IQ for blue-fin tune } \\
\text { contributes to the socioeconomic and environmental sustainability } \\
\text { in the mid-term. Two key drivers create right incentives: the co- } \\
\text { management system adopted to manage the quotas and, the } \\
\text { transference option. The economic Rofta and the profits increase a } \\
100 \% \text { with respect to the traditional top-down management model } \\
\text { accompanied of social benefits. }\end{array}$ \\
\hline & $\begin{array}{l}\text { North East Atlantic } \\
\text { pelagic fisheries }\end{array}$ & $\begin{array}{l}\text { One of the main challenges of the EU Common } \\
\text { Fisheries Policy is the overcapacity of } \\
\text { European fleets [63]. This is perceived as a } \\
\text { major obstacle to achieving economically } \\
\text { efficient fisheries [64]. One way to reduce } \\
\text { overcapacity is the implementation of ITQ } \\
\text { systems ([65],[66],[67]). A significant change } \\
\text { in fleet structure (mainly a reduction in vessel } \\
\text { numbers) is a generally observed response to } \\
\text { the transition from more open-access fisheries } \\
\text { to ITQ regimes and is considered the main }\end{array}$ & \begin{tabular}{|l|} 
The implementation of a new policy \\
instrument that allows the expansion of \\
national ITQ system to work across countries \\
is suggested in order to enable further fleet \\
reduction and economic efficiency gains. \\
More specifically, it is suggested to examine \\
the possible rent gains from expanding the \\
current mackerel and herring quota \\
management regimes in the Northeast \\
Atlantic, many of them ITQ- or ITQ-like \\
systems, to an international ITQ system,
\end{tabular} & $\begin{array}{l}\text { The impact assessment of the potential implementation of individual } \\
\text { tradable quotas across countries in the Northeast Atlantic mackerel } \\
\text { and herring fisheries was done by using the modelling tool IMPSEL } \\
\text { [71]. Assessments of the different degrees of tradability showed } \\
\text { overall improved economic gains from introducing the management } \\
\text { measure, compared to status quo. One of the critical issues arising } \\
\text { from the analysis are the political difficulties in implementing an } \\
\text { international ITQ system, which showed that even though there is a } \\
\text { total welfare gain from allowing mackerel and herring quotas to be } \\
\text { traded, there are still winners and losers. Consequently, the } \\
\text { countries that are expected to lose will strongly oppose the }\end{array}$ \\
\hline
\end{tabular}




\begin{tabular}{|c|c|c|c|c|}
\hline $\begin{array}{c}\text { MAIN } \\
\text { PROBLEMS }\end{array}$ & CASE STUDIES & PHASE I & PHASE II & PHASE III \\
\hline & & $\begin{array}{l}\text { mechanism of capacity reduction [68]. } \\
\text { Overcapacity reductions and fleet efficiency } \\
\text { increases have been demonstrated following the } \\
\text { introduction of national ITQ systems in a } \\
\text { number of fisheries ([68], [69]). If similar gains } \\
\text { can be obtained by introducing ITQ's across } \\
\text { countries, this method can be used to mitigate } \\
\text { the challenge of overcapacity in European } \\
\text { fisheries. }\end{array}$ & $\begin{array}{l}\text { where quotas can be traded across countries. } \\
\text { Stakeholders emphasized the method to be } \\
\text { political challenging, as it could lead to } \\
\text { significant catch redistributions between } \\
\text { countries. Furthermore, Irish Celtic Sea } \\
\text { herring fishermen attitude towards } \\
\text { introducing internationally traded quotas was } \\
\text { strongly negative, in contrast to the Danish } \\
\text { pelagic fishermen that had positive } \\
\text { preferences towards the method [70]. } \\
\text { Therefore, in order to have a politically and } \\
\text { industrial more acceptable way to introduce } \\
\text { internationally ITQ's, it was suggested to } \\
\text { allow only a certain degree of trade between } \\
\text { countries. This is examined as case study } \\
\text { scenarios }\end{array}$ & implementation of such a system. \\
\hline $\begin{array}{l}\text { F. Most pressing } \\
\text { issues for the } \\
\text { fisheries }\end{array}$ & $\begin{array}{l}\text { Icelandic inshore } \\
\text { handline fishery }\end{array}$ & $\begin{array}{l}\text { The Non-EU Iceland demersal fisheries } \\
\text { example is introduced to analyse the "global } \\
\text { picture" of the main governance issues, e.g. } \\
\text { ecosystem management options and co- } \\
\text { management as well as more technical aspects } \\
\text { such as discards (LO), certification and } \\
\text { subsidies. In order to map out the main } \\
\text { governance problems, semi-structured } \\
\text { interviews and focus groups were generally } \\
\text { conducted with representatives from industrial } \\
\text { fisheries and local governments. }\end{array}$ & $\begin{array}{l}\text { The non-EU Iceland demersal fisheries } \\
\text { received feedback from different } \\
\text { stakeholders, and a list of management } \\
\text { options was created that dealt with some of } \\
\text { the most pressing issues that came out from } \\
\text { the previous phase. Most stakeholders agreed } \\
\text { that profit maximization was, and should be, } \\
\text { the main aim of fisheries management and } \\
\text { that it should be based on sound scientific } \\
\text { principles and guidelines. When asked about } \\
\text { their views on whether more emphasis } \\
\text { should be based on ecosystem management } \\
\text { measures, they generally agreed on giving } \\
\text { such measures more weight. Furthermore, } \\
\text { LO were seen in a positive light especially as } \\
\text { it leads to more accurate catch data. }\end{array}$ & $\begin{array}{l}\text { For different reasons, it was not possible to carry out a thorough } \\
\text { analysis under phase III for the non-EU Icelandic case study and the } \\
\text { analysis carried only relied on qualitative information and } \\
\text { assessments. In particular, the later additions to the management } \\
\text { system, especially the introduction of a specific small-scale fishery, } \\
\text { provides some indications regarding effects of changes in } \\
\text { management on fishers' perception. These were especially targeted } \\
\text { in the semi-structured interviews with stakeholders. These changes } \\
\text { were regarded as being positive from those that participated in the } \\
\text { coastal fishery while those that did not pointed to low economic } \\
\text { performance of the coastal fishery in comparison with other fleets } \\
\text { under other management systems (ITQs) }\end{array}$ \\
\hline
\end{tabular}


Table 1 - Challenges, difficulties and solutions proposed in implementing the SIA

\begin{tabular}{|c|c|c|}
\hline MAIN CHALLENGES & MAIN DIFFICULTIES & SOLUTIONS \\
\hline $\begin{array}{l}\text { The value of using } \\
\text { qualitative information } \\
\text { from stakeholders }\end{array}$ & $\begin{array}{l}\text { Shortcomings of many models which may well be } \\
\text { theoretically and computationally refined but may lack } \\
\text { relevance to real-world situations }\end{array}$ & $\begin{array}{l}\text { The main solution is to advance towards the } \\
\text { incorporation of "soft" data, obtained by } \\
\text { interviewing and collecting information from } \\
\text { different stakeholders into the impact analysis } \\
\text { quantitative procedure. }\end{array}$ \\
\hline $\begin{array}{l}\text { The choice of a specific } \\
\text { model for each case study }\end{array}$ & $\begin{array}{l}\text { Guarantees the appropriateness of the model to address the } \\
\text { specificities of each fishery. However, high confusion is } \\
\text { created by the variety of approaches used (simulation vs. } \\
\text { optimization models). The drawback lies in the confusion } \\
\text { created by the variety of approaches used (simulation vs. } \\
\text { optimization models, degree of complexity of the } \\
\text { environmental and economic parts) which complicates the } \\
\text { communication of assumptions and results to stakeholders and } \\
\text { managers and the comparisons across case studies. }\end{array}$ & $\begin{array}{l}\text { Favour modular models, which complexity can be } \\
\text { adjusted to the question at stake. Check with } \\
\text { stakeholders that the representation of the system } \\
\text { provided by the model fits their perceptions and that } \\
\text { most important features and drivers are included. }\end{array}$ \\
\hline $\begin{array}{l}\text { Reconciliation between } \\
\text { environmental, economic } \\
\text { and social objectives }\end{array}$ & $\begin{array}{l}\text { Multi-species } \mathrm{F}_{\mathrm{MSY}} \text { ranges constraints and Bpa constraints, } \\
\text { socio-economic constrains on profit, employment, etc. }\end{array}$ & $\begin{array}{l}\text { Viability theory could thus help defining a set of } \\
\text { viable solutions respecting ecological, biological and } \\
\text { thus help proposing a bargaining space to find the } \\
\text { most acceptable and coherent solutions. }\end{array}$ \\
\hline $\begin{array}{l}\text { Effectiveness evaluation } \\
\text { criteria based on LEI and } \\
\text { TEI, generic enough to be } \\
\text { computed for each case } \\
\text { study and dimension }\end{array}$ & $\begin{array}{l}\text { Straightforward interpretation of model results both compared } \\
\text { to management targets and the current situation. A limit was } \\
\text { that comparison between TEI and LEI (obtained for different } \\
\text { targets and model outcomes) was not possible as calculated in } \\
\text { a different way }\end{array}$ & $\begin{array}{l}\text { TEI and LEI were further summarised using a very } \\
\text { visual colour code }\end{array}$ \\
\hline Coherence evaluation. & $\begin{array}{l}\text { Multidisciplinary approach with different dimensions } \\
\text { (environmental, economic and social). Evaluation problem of } \\
\text { the trade-off between these dimensions }\end{array}$ & $\begin{array}{l}\text { An attempt to overcome this problem is done by } \\
\text { using the coherence indicator, which represents the } \\
\text { limitation of the necessary trade-offs. Furthermore, } \\
\text { future SIA improvements should consider the way of } \\
\text { producing a more balanced (among dimensions) } \\
\text { integrated sustainability indicator. Indeed, the issue } \\
\text { of substitutability or compensability across } \\
\text { dimensions remains delicate and unsolved (see for } \\
\text { instance [77]). }\end{array}$ \\
\hline Efficiency evaluation & $\begin{array}{l}\text { It requires the estimation of management costs and social } \\
\text { benefits which are hardly available and modelled }\end{array}$ & $\begin{array}{l}\text { It is used the net present value of the profit of the } \\
\text { fishery (hence focusing on the private sector) as a } \\
\text { proxy, which was computable by every model but } \\
\text { restricted the significance of the criteria. An essential } \\
\text { improvement of the method could be to better define } \\
\text { which are the main management costs to include in } \\
\text { the analysis, being them essential for policy makers } \\
\text { to take the best possible decision. }\end{array}$ \\
\hline $\begin{array}{l}\text { Evaluation of the } \\
\text { robustness of the } \\
\text { diagnostic }\end{array}$ & $\begin{array}{l}\text { The amount of results to be managed increases rapidly with } \\
\text { the multiplication and possible combination of risk scenarios } \\
\text { and is hardly summarised by a single value such as standard } \\
\text { deviation provided by risk analyses. Here such risk analyses } \\
\text { were not considered, mainly because it requires the evaluation } \\
\text { of the likelihood of an event to occur, a delicate and sensitive } \\
\text { task. }\end{array}$ & $\begin{array}{l}\text { Here the influence of external factors on the } \\
\text { achievement of management goals was assessed } \\
\text { using a scenario approach very straightforward to } \\
\text { interpret. } \\
\text { The computation of sensitivity indices is also an } \\
\text { option and requires the building of a statistically } \\
\text { appropriate design of simulations. Finally, it must be } \\
\text { noted that here only robustness to external factors } \\
\text { was considered while the quantitative nature of } \\
\text { mathematical models should not hide their inherent } \\
\text { uncertainty. }\end{array}$ \\
\hline
\end{tabular}

